$$
\text { UNIVERSIDADE DE BRASÍLIA }
$$

INSTITUTO DE CIÊNCIA POLÍTICA E RELAÇÕES INTERNACIONAIS

DEPARTAMENTO DE RELAÇÕES INTERNACIONAIS

IX CURSO DE ESPECIALIZAÇÃO EM RELAÇÕES INTERNACIONAIS - 2007

\title{
A TENTATIVA DE REMILITARIZAÇÃO DO JAPÃO NO SÉCULO XXI: ANTECEDENTES HISTÓRICOS E IMPLICAÇÕES CONTEMPORÂNEAS
}

DANIELLA MATSUNAGA SASAKI, matrícula 07/58540

Orientadora: PROF ${ }^{a}$ MARIA IZABEL VALLADÃO DE CARVALHO

\begin{abstract}
Monografia final apresentada ao Instituto de Relações Internacionais como requisito parcial para obtenção do Certificado de Especialista em Relações Internacionais pelo Instituto de Ciência Política e Relações Internacionais da Universidade de Brasília - UnB.
\end{abstract}


UNIVERSIDADE DE BRASÍLIA

INSTITUTO DE CIÊNCIA POLÍTICA E RELAÇÕES INTERNACIONAIS

DEPARTAMENTO DE RELAÇÕES INTERNACIONAIS

IX CURSO DE ESPECIALIZAÇÃO EM RELAÇÕES INTERNACIONAIS - 2007

\section{A TENTATIVA DE REMILITARIZAÇÃO DO JAPÃO NO SÉCULO XXI: ANTECEDENTES HISTÓRICOS E IMPLICAÇÕES CONTEMPORÂNEAS}

Daniella Matsunaga Sasaki 
Aos meus pais 


\section{AGRADECIMENTOS}

À minha orientadora Professora Maria Izabel Valladão de Carvalho, pela atenção, paciência e valorosa orientação.

À Madalena Iriyoda, pela ajuda na busca de bibliografia.

À Primeira Secretária Sakiko Hayakawa, pela compreensão durante a realização de minha monografia.

Aos meus pais e irmãos pelo apoio.

A todos que, direta ou indiretamente, colaboraram na realização deste trabalho. 


\section{RESUMO}

SASAKI, Daniella Matsunaga. A tentativa de remilitarização do Japão no século XXI.

Com o fim da Segunda Guerra Mundial e a derrota do Japão, este foi ocupado pelos Estados Unidos em nome dos aliados. Como uma das conseqüências, houve a promulgação da nova constituição japonesa, em 1946, que perdura até os dias de hoje sem qualquer modificação e incluindo a polêmica cláusula de renúncia à guerra. Militarmente, o Japão hoje possui as chamadas Forças de Autodefesa (Dietai), que tem como objetivo apenas a sua defesa. Em boa parte, os japoneses ainda dependem do Tratado de Segurança e Cooperação Mútua com os Estados Unidos, cuja primeira versão foi assinada em 1951, após o período de ocupação americana. Porém seus vizinhos, cujas histórias de inimizades são históricas na região, Coréia do Norte (somente Coréia na época), China e Rússia, têm demonstrado que rivalidades antigas permanecem. Episódios recentes de violações do espaço aéreo e testes de mísseis no Mar do Japão servem como motivação para uma possível remilitarização do Japão. Enquanto isso, o cenário político japonês parece ter começado o século XXI caminhando nesta direção, com a eleição de Junichiro Koizumi e Shinzo Abe ao cargo de primeiro-ministro, ambos com abertas intenções de revisão constitucional. Mas com a renúncia de Abe e a subida ao poder do moderado de Yasuo Fukuda, em setembro de 2007, o futuro da revisão constitucional fica em suspenso.

\section{ABSTRACT}

By the end of the Second World War and the defeat of Japan, the United States in the name of the Allies occupied the Japanese territory. As one of the consequences a new Japanese constitution was promulgated in 1946, and it remains until today without any modifications, including the Renunciation of War article. Nowadays, Japan has the SelfDefense Forces (Dietai), which objectives are only defense of the country. The Japanese still depends on the Treaty of Mutual Cooperation and Security between Japan and the USA, which first version was signed in 1951, after the Occupation period. Japan's neighbours, historical enemies in that region, North Korea (by that time, was only Korea), China and Russia, have shown that ancient rivalry still remains today. Recent episodes, like the violation of the Japanese airspace and missiles tests over the Sea of Japan, may motivate Japan for its re-militarization. Meanwhile, the Japanese political scenario seemed to start the XXI century taking the re-militarization path, with Junichiro Koizumi and Shinzo Abe elections for prime-minister, both with constitutional revision open intensions. But when Abe renounced, the moderated Yasuo Fukuda became prime-minister in September of 2007, which means that the constitutional revision future is suspended. 
LISTA DE FIGURAS

Figura 1 - Forças Militares dos EUA no Japão..................................................................43

Figura 2 - Forças de Autodefesa do Japão..................................................................44 


\section{LISTA DE TABELAS}

Tabela 1 - Gastos anuais em defesa de acordo com o orçamento inicial. .40

Tabela 2 - Comparação dos gastos na defesa nacional. 40

Tabela 3 - Forças militares dos EUA no Japão (em terra). 41

Tabela 4 - Potencial militar das Forças de Autodefesa. .42

Tabela 5 - Forças militares (2005). .51

Tabela 6 - Potencial militar na península coreana...... 53

Tabela 7 - Potencial militar na China. 54 


\section{SUMÁRIO}

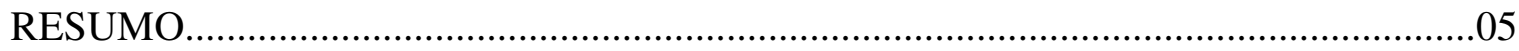

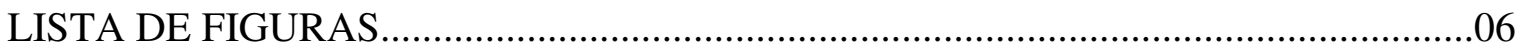

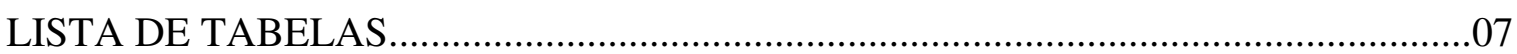

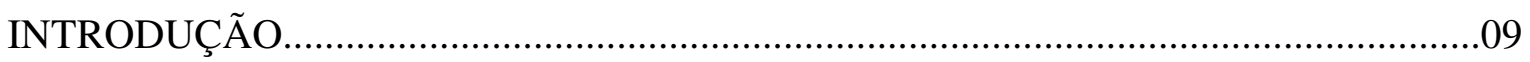

CAPÍTULO 1 - O JAPÃO EXPANSIONISTA E A SUA VIZINHANÇA........................11

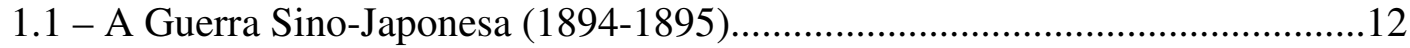

1.2 - A Guerra Russo-Japonesa (1904-1905).......................................................13

1.3 - A anexação da Coréia (1910).......................................................................16

1.4 - A I Guerra Mundial (1914-1917)............................................................17

1.5 - A II Guerra Mundial (1939-1945)...........................................................20

CAPÍTULO 2 - O FIM DA SEGUNDA GUERRA MUNDIAL E A

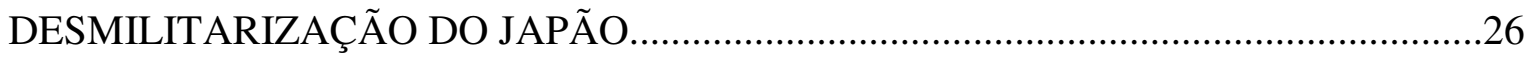

2.1 - A constituição "MacArthista" ....................................................................29

CAPÍTULO 3 - A TENTATIVA DE REMILITARIZAÇÃO NO INÍCIO DO SÉCULO

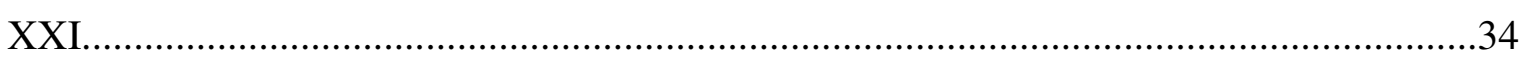

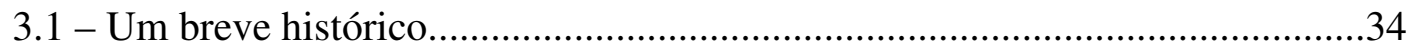

3.2 - O Ministério da Defesa do Japão hoje.............................................................36

3.3 - De Junichiro Koizumi (2001 a 2006) a Shinzo Abe (2006 e 2007)..............45

CAPÍTULO 4 - O CENÁRIO INTERNACIONAL NO EXTREMO ORIENTE..............50

4.1 - Motivações e estatísticas.......................................................................50

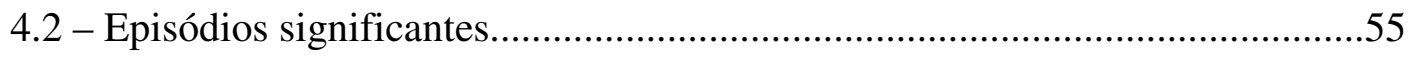

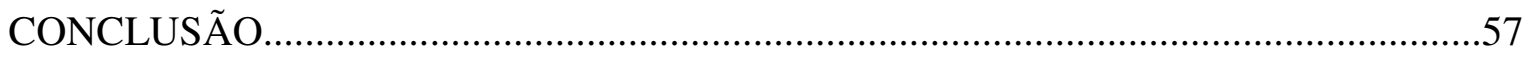

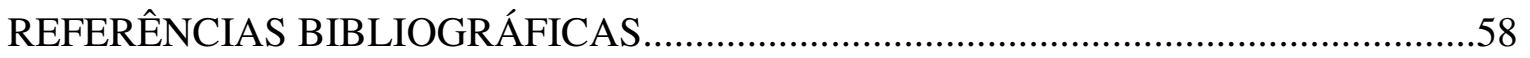




\section{INTRODUÇÃO}

Esta monografia tem por objetivo compreender o porquê de haver a intenção dos japoneses de uma possível remilitarização neste início de século, para tanto fazendo uma contextualização histórica desde o final do século XIX até o período de ocupação após o término da Segunda Guerra Mundial, e analisando o cenário doméstico japonês e internacional daquela região. $\mathrm{O}$ tema pode parecer antigo, já que o Japão não possui forças militares desde o fim da II Guerra, mas a sua atualidade está no fato de líderes japoneses, como os ex-primeiros-ministros Junichiro Koizumi e Shinzo Abe, defenderem abertamente a revisão do artigo 9 da Constituição do Japão, no qual está a polêmica cláusula de renúncia a guerra. Os japoneses dependem amplamente de suas relações com os Estados Unidos, principalmente no Tratado de Segurança e Cooperação Mútua que existe entre os dois países e de certa forma oficializou a manutenção de bases militares norte-americanas em território nipônico.

O que, na verdade, torna a temática significativa nos dias de hoje são episódios cada vez mais freqüentes de incidentes militares envolvendo o Japão e seus vizinhos, China, Coréia do Norte e Rússia. Em 2006, a Coréia do Norte lança sete mísseis que caem no Mar do Japão e no mesmo ano se vangloria de ter realizado um teste nuclear subterrâneo com sucesso. Outro exemplo ainda mais recente é o relato de invasão de espaço aéreo pelo recém-criado Ministério da Defesa japonês, no qual um bombardeiro russo Tupolev Tu-95, em fevereiro de 2008. E são episódios como esses que podem gerar instabilidade no leste asiático e, quem sabe, ocasionar uma corrida armamentista. Mas será que isso já não pode estar acontecendo de forma velada e sutil? Afinal, essas são razões aparentemente suficientes para o Japão temer por sua segurança.

Esta monografia está divida em quatro capítulos, de maneira que no primeiro capítulo há a contextualização histórica, narrando, a partir da Constituição Meiji, como o Japão se torna expansionista. É um período de intensas guerras em que o Japão se envolve, como a Guerra Sino-Japonesa, a Guerra Russo-Japonesa e a II Guerra Mundial. O objetivo é compreender como surgem as tensões e inimizades na região.

Já no capítulo dois, é descrito o período de ocupação do Japão realizado pelos Estados Unidos, em nome dos aliados, logo após o fim da Segunda Guerra. É nesse capítulo em que se compreende a realização da nova constituição japonesa "imposta" pelos 
norte-americanos em prol da democracia. É nessa nova carta magna, intacta até hoje, que há o polêmico artigo de renúncia à guerra.

O terceiro capítulo trata sobre o Japão no século XXI, seu cenário político e o recém-criado Ministério da Defesa, até 2006 ainda era Agência de Defesa, criada em 1954. Além disso, são expostos dados atualizados sobre as Forças de Autodefesa do Japão (Dietai) e as forças militares do EUA no Japão; em ambos os casos com mapas dos locais em que se encontram.

O cenário internacional no leste asiático é o assunto do quarto e último capítulo desse ensaio. Os vizinhos e inimigos históricos do Japão, Rússia, China e Coréia do Norte são o foco desta seção, na qual será possível compreender motivações e observar algumas estatísticas militares dos mesmos. Além disso, alguns episódios significantes entre essas nações e os japoneses, acontecidos neste século e considerados incidentes diplomáticos, são permeados, o que podem ser considerados grandes motivadores de uma possível remilitarização nipônica.

O que se compreenderá nesta monografia é o fato do Japão ter motivações externas suficientes para se preocupar e é o que seus recentes primeiros-ministros têm demonstrado, com a possibilidade iminente de uma revisão constitucional, o que incluiria o artigo 9 sobre a guerra. De um modo geral, é possível dizer que as inimizades regionais são frutos de um expansionismo japonês que aconteceu no início do século passado. 


\section{O JAPÃO EXPANSIONISTA E A SUA VIZINHANÇA}

Este primeiro capítulo visa fazer uma breve contextualização histórica a partir do momento em que o Japão se torna expansionista, desestabilizando o leste da Ásia. O marco inicial adotado aqui é a adoção de sua primeira constituição, se estendendo até o fỉm da II Guerra Mundial. Neste ínterim, os japoneses tentaram conquistar e dominar seus vizinhos, principalmente a Coréia e a China, o que motivou o ódio aos nipônicos não apenas dessas nações, mas despertando a ira da Rússia e dos Estados Unidos, ambos com interesses naquela região. E essas ações externas do Japão tiveram conseqüências avassaladoras, com a desmilitarização forçada principalmente pelos EUA, como será visto no capítulo 2.

A primeira constituição japonesa foi promulgada em 11 de fevereiro de 1889, cerca de vinte anos após o início da Restauração Meiji em $1868^{1}$, ficando conhecida como a Constituição Meiji - a primeira carta magna formalmente adotada no oriente e fez do Japão a primeira nação a ter igualdade diplomática com o ocidente ${ }^{2}$. A data coincidia com o que os japoneses acreditavam ter sido a criação do Estado Japonês, em 11 de fevereiro de 660 a.C. O papel do imperador era considerado de extrema importância e a constituição fora considerada uma "dádiva do imperador ao seu povo", porém na prática o poder imperial não era absoluto como o descrito, necessitando que todos os decretos obtivessem a ratificação de um ministro de Estado $^{3}$.

A verdade é que mesmo após a promulgação da constituição, o Japão continuava absolvendo e aprendendo com a ciência e tecnologia do ocidente. Reischauer diz que dois caminhos foram tomados com isso: em sua política externa, o Japão se tornou uma grande força imperialista; enquanto internamente, se distanciava cada vez mais da democracia parlamentar. Contraditoriamente à tendência ocidental, já que tanto a Alemanha, quanto a França, eram grandes impérios, ao mesmo tempo em que também eram democracias. Até então, a única tentativa que ele havia feito para conquistar outros territórios ocorrera três séculos antes, e logo no início da Era Meiji, em 1873, houve uma demanda interna para

\footnotetext{
${ }^{1}$ Ver Inoue, 1991, p.38. O período conhecido como Restauração Meiji teve como objetivo a criação de um novo governo central que pudesse tomar o lugar do xogunato (Era Tokugawa). Foi uma revolução silenciosa, cuja intenção primária era adquirir a tecnologia necessária para a modernização e desenvolvimento de seu poderio militar, de modo que pudesse rivalizar com o ocidente, mas o que foi alegado por seus líderes foi o de modernizar o país aos moldes do ocidente. Sua capacidade de assimilação das influências externas sem comprometer a integridade de sua cultural ou sistema social foi o diferencial.Ver Barnett, 1977, p.90 e Reischauer, 1970, p.121.

2 Ibidem, p.144.

${ }^{3}$ Ver Henshall, 2004, p.126.
} 
uma expedição militar na Coréia, supostamente em resposta àquele país ter negado a abrirse ao Japão, mas que de fato seria uma forma de empregar os samurais empobrecidos ${ }^{4}$. Para Kenneth Henshall, na década de 1890 ainda havia a ameaça de colonização no oriente por parte das grandes potências ocidentais.

Um incidente externo já havia feito o Japão anexar as Ilhas Ryukyu como a província de Okinawa, em 1879. Em 1874, uma expedição havia sido montada para combater alguns nativos de Taiwan, que haviam matado marinheiros okinawanos. Quando o governo chinês pagou a indenização pelo episódio, ficou clara a intenção nipônica de soberania sobre as Ilhas Ryukyu ${ }^{5}$. Este foi o início do ambicioso programa expansionista japonês que desejava a supremacia regional ${ }^{6}$.

\subsection{A GUERRA SINO-JAPONESA (1894-1895)}

Era uma questão de tempo para que uma invasão à Coréia se tornasse realidade. Com a China sendo cobiçada por diversos países ocidentais, o Japão acabou aceitando esses termos com a intenção de também lucrar na divisão do "melão chinês". Tornava-se óbvio também, que a Coréia era local de fundamental importância estratégica para o Japão ${ }^{7}$. Em 1876, a exemplo da "diplomacia da cachoeira" (tratados com termos desiguais), utilizada pelo ocidente com o Japão, este conseguiu forçar a Coréia a assinar seu primeiro tratado moderno e abrir-se ao exterior ${ }^{8}$. O chamado Tratado de Kangwha concedeu vantagens comerciais e o direito de extraterritorialidade aos japoneses. A partir daquele momento eles começaram a envolver-se na política coreana, o que fez despertar a rivalidade com os chineses que também tinham interesse naquele território e possuíam grande influência ${ }^{9}$.

Com a pressão chinesa sobre a Coréia crescendo nos anos de 1880, o exército e a marinha japoneses desenvolveram-se para que esses estivessem prontos para agir em missões no exterior. Em 1884, o major alemão Jakob Meckel chega ao Japão, a pedido do próprio governo japonês, para ensinar aos oficiais japoneses um novo modelo de

\footnotetext{
${ }^{4}$ Ver Reischauer, 1970, p.145-6.

${ }^{5}$ Ver Reischauer, loc. cit.

${ }^{6}$ Ver Barnett, 1977, p.90.

${ }^{7}$ Ver Reischauer, 1970, p.146.

${ }^{8}$ Ver Reischauer, loc. cit.

${ }^{9}$ Ver Henshall, 2004, p.128.
} 
planejamento e filosofia política. Foi a convicção de Meckel que permeou entre seus pupilos, dizendo que a Coréia, se utilizada por outra potência, seria "um punhal apontado ao coração do Japão" ${ }^{\prime 10}$. Para se ter uma visão do investimento militar japonês, entre 85 e 95 , foram gastos um terço do orçamento anual na defesa nacional ${ }^{11}$.

Em 1894, o rei da Coréia pede ajuda militar à China para conter e pôr um fim a rebelião Tonghak ${ }^{12}$, liderada por uma seita religiosa. Não apenas a China enviou tropas, como também fez os japoneses. Em pouco tempo a rebelião havia sido contida, mas nenhum dos dois países saiu de terras coreanas. Dispostos a lutar, os japoneses iniciam suas investidas militares contra os chineses e, em 1 de agosto, declara guerra oficialmente ${ }^{13}$.

Apesar de reticentes inicialmente, os japoneses venceram facilmente a China, para assombro das potências ocidentais ${ }^{14}$. Adentrando a Coréia e a Manchúria, os japoneses puderam demonstrar sua superioridade tática naval baseada no modelo britânico, ocupando o porto de Weihaiwei, ao norte da China, e destruindo a frota chinesa em fevereiro de 95. Em abril, é assinado o Tratado de Shimonoseki, dando fim a Guerra Sino-Japonesa, mas com sérias conseqüências aos perdedores. De acordo com o tratado, a China deveria pagar uma alta indenização; admitir a total independência da Coréia; aceitar um acordo desigual com Japão, fornecendo os mesmos privilégios diplomáticos e comerciais que as potências ocidentais haviam extorquido para conseguir algum tempo antes; além de ter de ceder as ilhas de Taiwan, Pescadores e a península de Liaotung/Kwantung (Liaodong/Guandong), situada no sul da Manchúria ${ }^{15}$.

O ocidente estava bastante atento às ações de seu pupilo oriental, elogiando suas conquistas $^{16}$. Estava dado o primeiro passo para a construção do império japonês na Ásia ${ }^{17}$.

\subsection{A GUERRA RUSSO-JAPONESA (1904-1905)}

A Rússia tinha interesses tanto na Coréia, quanto na Manchúria e, apenas uma semana após a assinatura do Tratado de Shimonoseki, conseguiu mobilizar Alemanha e

\footnotetext{
${ }^{10}$ Ver Crowley, 1974, p.11.

${ }^{11}$ Ver Katzenstein, 1996, p.55.

${ }^{12}$ Ver Crowley, 1974, p.15.

${ }^{13}$ Ver Henshall, 2004, p.129.

${ }^{14}$ Ver Reischauer, 1971, p.147.

${ }^{15}$ Ibidem, p.147 e Henshall, loc. cit.

${ }^{16}$ Ver Reischauer, 1971, p.147.

${ }^{17}$ Ver Henshall, loc. cit.
} 
França a juntarem-se na Intervenção Tripartida. O objetivo era pressionar o Japão a renunciar a península de Liaotung, alegando que haveria uma instabilidade na região ${ }^{18}$, já que seria "uma constante ameaça a capital da China, ao mesmo tempo em que criaria uma

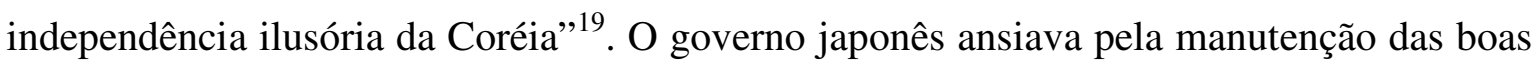
relações com o ocidente e acatou a Intervenção Tripartida ${ }^{20}$, um ato considerado por seu povo uma humilhação pública e atestado de fraqueza de suas forças militares ${ }^{21}$.

Ironicamente, apenas três anos mais tarde, em 1898, as mesmas potências começaram a dividir regiões da China ${ }^{22}$. Quando a Alemanha tomou Shantung, a Rússia tomou para si a península de Liaotung, o que impeliu a Grã-Betanha a estabelecer uma base naval em Weihaiwei ${ }^{23}$.

Os japoneses tiveram de engolir seu orgulho, mas logo já se debatia internamente sobre o inevitável choque com a Rússia, que já dominava a Manchúria e começava a ter cada vez mais influência sobre a Coréia ${ }^{24}$.

O cenário japonês parecia ter melhorado, agora com o respeito das grandes nações ocidentais obtido pela vitória na Guerra Sino-Japonesa e com a revisão ao menos em parte de seus tratados desiguais, principalmente o acordado com a Grã-Betanha, que apenas algumas semanas antes da guerra de 1894 concordou em restaurar parcialmente a autonomia aduaneira do Japão e abandonar o seu direito de extraterritorialidade. Mesmo assim, sua política interna estava caótica, com duras críticas aos governantes sobre o caso da Rússia. Apenas para se ter uma visão geral do que se desenrolava internamente, basta dizer que, entre 1896 e 1901, mudou-se sete vezes de primeiro-ministro e uma relativa estabilidade interna apenas retornou quando, novamente, um assunto externo era mais importante: a Guerra Russo-Japonesa ${ }^{25}$.

Em janeiro de 1900, a Revolução dos Boxers se inicia no norte da China, quando sociedades secretas de kung fu foram conclamadas pela imperatriz Dowager Ci Xi para combater os estrangeiros. Em princípio os alvos eram missionários católicos e chineses convertidos, mas logo passariam a ser as missões diplomáticas estrangeiras. Para se protegerem, as missões da Inglaterra, da França, da Noruega, da Espanha, da Bélgica, da

\footnotetext{
${ }^{18}$ Ibidem.

${ }^{19}$ Ver Crowley, 1974, p.16.

${ }^{20}$ Ver Henshall, loc. cit.

${ }^{21}$ Ver Crowley, op. cit., p.17.

${ }^{22}$ Ver Henshall, loc. cit.

${ }^{23}$ Ver Crowley, loc. cit.

${ }^{24}$ Ver Reischauer, loc. cit.

${ }^{25}$ Ver Henshall, 2004, p.130-1.
} 
Rússia, do Japão e dos Estados Unidos se uniram e formaram o Exército das Oito Nações ${ }^{26}$. Em agosto a revolta já havia sido esmagada, mas apenas a Rússia se recusou a retirar suas tropas do território chinês, o que causou consternação das outras sete nações, e em especial do Japão.

O governo nipônico almejava um acordo com a Rússia, de modo que ela reconhecesse os interesses japoneses na Coréia, enquanto o Japão reconheceria os interesses russos na Manchúria. No entanto a estratégia não deu certo e a Rússia se opôs ao possível acordo $^{27}$. Não restava ao Japão outra solução, a não ser arranjar uma aliança ocidental para que não enfrentasse outra coalizão de potências européias. Assim, em janeiro de 1902, surgiu o primeiro pacto militar em igualdade de condições entre o ocidente e uma nação não ocidental: a Aliança Anglo-Japonesa. Apesar do pacto não dizer que a Grã-Bretanha combateria ao lado do Japão na futura guerra ${ }^{28}$, protegeria os japoneses de uma repetição da Intervenção Tripartida de $1895^{29}$, além de assegurar a improbabilidade de outras potências entrarem na guerra contra o Japão ${ }^{30}$.

Em 1902, o Império do Sol Nascente já possuía poderio militar suficiente para enfrentar a Rússia, fruto de dez anos do programa de expansão de armamentos, adotado desde 1896 pelo governo japonês e com gastos de mais da metade do seu orçamento anual. O exército contava com treze divisões (170 mil homens) e com a possibilidade de mobilizar 600 mil em períodos de guerra, além do aumento considerável da frota naval imperial $^{31}$.

Em 6 de fevereiro de 1904, o Japão suspende as relações diplomáticas com a Rússia, atacando seus navios em Port Arthur dois dias depois e declarando guerra no dia $10^{32}$. A verdade era que a Rússia era militarmente bastante superior aos japoneses ${ }^{33}$, porém sofria algumas desvantagens naquele momento, a Revolução de 1905 acontecia internamente e com o Canal de Suez fechado pelos britânicos, o desvio que tinham de fazer

\footnotetext{
${ }^{26}$ Ver Martins, 2007, p.55-6. As conseqüências da Revolta dos Boxers foram: a assinatura do Protocolo Boxer, que garantiria a paz entre a China e as oito nações; as execuções de dez oficiais de alta patente ligados ao episódio; além da indenização de 150 milhões de tiangs (mais de 650 milhões de reais), que poderia ser paga em até 39 parcelas anuais, com 4\% de juros ao ano (em 1939, o valor chegou ao equivalente de 1,3 bilhão de reais). Ibidem, p.59.

${ }^{27}$ Ver Henshall, 2004, p.131.

${ }^{28}$ Ver Henshall, loc. cit.

${ }^{29}$ Ver Crowley, 1974, p.19.

${ }^{30}$ Ver Henshall, loc. cit.

${ }^{31}$ Ver Crowley, loc. cit.

${ }^{32}$ Ver Henshall, 2004, p.131-2.

${ }^{33}$ Ver Reischauer, 1971, p.148.
} 
era ainda mais longo e desgastante ${ }^{34}$. Os russos enviaram a sua frota naval do Mar Báltico para o Pacífico contornando a África ${ }^{35}$, fazendo uma breve parada em Vladivostoque. Mas a Frota Japonesa Conjunta interceptou e destruiu os russos nos Estreitos de Tsushima, entre o Japão e a Coréia.

Secretamente os japoneses pediram ao presidente dos Estados Unidos, Theodore Roosevelt, para mediar o fim da guerra. Em setembro de 1905, foi assinado o Tratado de Portsmouth, no qual a Rússia reconhecia os interesses japoneses na Coréia, transferia o arrendamento da península de Liaotung dos russos ao Japão e, também, a ferrovia construída por eles no sul da Manchúria, que agora era devolvida à China. E, contrariando as expectativas nipônicas que havia se endividado com os britânicos e os americanos para fazer a guerra, não receberam uma indenização, mas sim a metade da Ilha Sacalina, situada ao norte de Hokkaido. O Japão era a primeira nação não ocidental a ganhar uma guerra de uma nação ocidental ${ }^{36}$.

\subsection{A ANEXAÇÃO DA CORÉIA (1910)}

Em novembro de 1945, o governo coreano foi pressionado a tornar-se um protetorado do Japão, já que o seu exército fora dissolvido pelos ocupantes japoneses, o que exigiria a suposta proteção. Inclusive soldados nipônicos ocuparam o Palácio Real, funcionários coreanos foram substituídos por nipônicos e Hirobumi Ito (figura influente no cenário político que havia sido primeiro-ministro) se tornou general-presidente da Coréia.

Apesar dos protestos coreanos no ocidente, as grandes potências ignoraram o que estava acontecendo ${ }^{37}$. Foram 1450 repressões armadas feitas por tropas nipônicas contra os revoltosos coreanos, entre 1908 e $1910^{38}$. Inclusive com Ito sendo assassinado em 1909.

Em 1910, sem resistência ou oposição de qualquer outra nação, o Japão anexa a Coréia $^{39}$, implementando um programa de desenvolvimento econômico e exploração, trazendo ferrovias e fábricas modernas, assim como fazia em Taiwan. Mas em ambos os casos, o regime nipônico era opressor e repreensivo por meio da força policial. No caso da

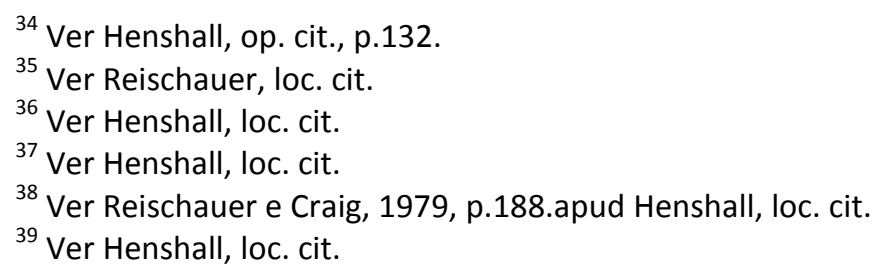


Coréia, o povo era orgulhoso de sua homogeneidade e mantinha seu sistema burocrático central baseado no modelo chinês há mais de mil anos. Era de se esperar que o povo coreano odiasse essa colonização japonesa ${ }^{40}$.

\subsection{A I GUERRA MUNDIAL (1914-1917)}

Em 7 de agosto de 1914, o governo britânico pede formalmente a ajuda naval do Japão para combater a esquadra imperial alema ${ }^{41}$. Indo a guerra, os Japoneses perceberam a boa oportunidade de incorporar novos territórios sem grandes riscos ou esforços. Sem interesses maiores na guerra que assolava a Europa e apenas nominalmente envolvido na guerra, o império nipônico aproveitou para tomar as colônias alemãs do leste: Tsingtao na costa da China, todos os interesses germânicos nos arredores da província de Shantung e as ilhas Marianas, Carolinas e Marshalls, no Pacífico Norte (designadas ao Japão mais tarde, pela Conferência de Paz de Versalhes) ${ }^{42}$.

Em 1915, aproveitando-se das atenções do mundo voltadas à Europa, o Japão apresenta, o que ficou conhecido como, as Vinte e Uma Exigências à China, na qual exigia o reconhecimento chinês das possessões japonesas, mesmo as recém-adquiridas da Alemanha, e mais concessões na Mongólia, na Manchúria ${ }^{43}$ e na província de Fukien. O governo de Pequim ainda conseguiu resistir a algumas exigências, assinando uma série de tratados, incorporando a maior parte das exigências originais japonesas ${ }^{44}$. Se tivessem aceitado todas as demandas, teriam se tornado um protetorado virtual do Japão ${ }^{45}$. Essas exigências causaram certa preocupação ao ocidente e principalmente aos Estados Unidos ${ }^{46}$.

Com esses tratados, a posição militar nipônica foi fortalecida nos arredores da Coréia e de Taiwan, fornecendo uma sólida base para a ampliação de suas atividades comerciais na região ${ }^{47}$. Com a guerra na Europa e o florescimento industrial no Japão, os

\footnotetext{
${ }^{40}$ Ver Reischauer, 1971, p.150.

${ }^{41}$ Ver Crowley, 1974, p.32.

${ }^{42}$ Ver Reischauer, loc. cit.

${ }^{43}$ Ver Henshall, 2004, p. 154.

${ }^{44}$ Ver Crowley, 1974, p.33.

${ }^{45}$ Ver Reischauer, 1971, p.151.

${ }^{46}$ Ver Henshall, loc. cit.

${ }^{47}$ Ver Crowley, loc. cit.
} 
japoneses conseguiram dominar os mercados na Ásia, antes monopolizados pelos europeus $^{48}$.

Em 1919, na Conferência de Paz de Versalhes, sob o status de membro aliado vitorioso, também teve posição de destaque e tendo direito de voto como as outras nações vitoriosas. Em 1920, foi um dos membros fundadores da Liga das Nações e pertencia ao seu Conselho, no entanto não conseguiu incluir na Carta da Liga sua proposta de uma norma sobre o igual tratamento racial, o que o irritou bastante. Outro episódio que exalta novamente os ânimos no Japão é a Conferência de Washington (1921-1922), quando é obrigado a concordar com um limite de três navios de primeira linha, enquanto Estados Unidos e Grã-Bretanha tinham um limite de cinco ${ }^{49}$.

Os americanos adotaram a partir de 1921 uma política, em parte baseada na Conferência de Washington, de contenção ao expansionismo japonês: “(a) impedir a renovação da aliança anglo-japonesa de 1902; (b) limitar a força naval japonesa; (c) compromisso por parte do Japão de respeitar a independência e as 'portas abertas'da

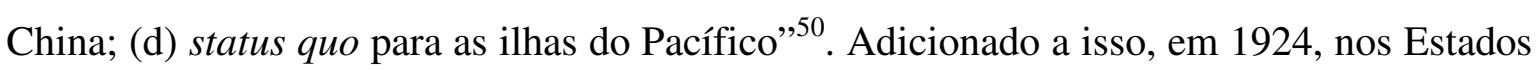
Unidos, é aprovada a Lei de Imigração que proibia a imigração japonesa, outro fato que causou indignação ao povo japonês e que, conseqüentemente, enfraquecia a motivação nipônica de cooperar com os norte-americanos, de acordo com a Conferência de Washington ${ }^{51}$.

Amado Luiz Cervo indica em seu texto que o Japão era posto em xeque, nos anos 1920, com três alternativas possíveis: (a) conciliação com o ocidente, caso não pudesse enfrentá-los; (b) investir em sua autonomia com base regional, evitando o confronte com os ocidentais; e (c) confrontar a nova ordem internacional, na tentativa de quebrar com o status quo. Se a opção nipônica oscilava entre as alternativas (a) e (b) nos anos 20, nos anos 30 , ficava entre (b) e (c) $)^{52}$.

Em 25 de dezembro de 1926, com a morte do imperador Yoshihito e o fim da Era Taishō, o imperador Hirohito toma posse como imperador e se inicia a Era Shōwa ${ }^{53}$, A situação interna era bastante frágil naquele momento, o desenvolvimento industrial e comercial com tecnologia ocidental foi aliado a mão-de-obra barata, porém desqualificada.

\footnotetext{
${ }^{48}$ Ver Reischauer, loc. cit.

${ }^{49}$ Ver Henshall, 2004, p.154-5.

${ }^{50}$ Ver Cervo, 2007, p.149.

${ }^{51}$ Ver Henshall, loc. cit.

${ }^{52}$ Ver Cervo, loc. cit.

${ }^{53}$ Ver Henshall, 2004, p.156.
} 
Isso fez com que houvesse uma grande concentração econômica de poucas famílias industriais (zaibatsu) ${ }^{54}$. Em 27, uma grande crise financeira assolou o Japão e um quarto dos bancos pediu falência. Em conseqüência à industrialização, a população urbana crescia exponencialmente e os problemas sociais também ${ }^{55}$. Adicionados a esses problemas estavam: a coerção americana, a escassez de matéria-prima, a classe dirigente militarista estava cada vez mais poderosa, não se conseguia exportar devido ao protecionismo, e nem importar pela baixa capacidade financeira ${ }^{56}$.

Após a "liberal" década de 20, caracterizada pela "democracia Taishō", é seguida do retorno ao expansionismo militarista e a rigidez autoritária interna, na década de $30^{57}$. Em 1931 acontece o Incidente da Manchúria, quando o exército japonês na Manchúria, Kwantung, visava o fortalecimento da posição militar na região, explodindo uma ferrovia e colocando a culpa nos chineses. Essa era a mesma estratégia de 28, quando tentaram, sem sucesso, uma intervenção militar na área, explodindo um trem perto de Mukden, que levou a morte do senhor da guerra Chang Tso-lin, e culpando supostos bandidos chineses. No episódio de 1931, a intervenção japonesa veio poucas horas depois, levando mais tarde a forjarem uma independência da Machúria, estabelecendo, pelo exército Kwantung, a República de Machukuo em março de 32. Dois anos depois, já reconhecido formalmente pelo governo japonês, a república se torna o Império de Manchukuo e seu líder fantoche era o famoso "último imperador" (da dinastia Manchu) Puyi ${ }^{58}$.

A China apela para a Sociedade das Nações, menos pelo Incidente da Manchúria e mais pelo fato do Japão estar em guerra em outras áreas de seu vasto território ${ }^{59}$. Apesar da Sociedade ter enviado uma comissão a Manchúria em 32 e, em 33, ter condenado as ações japoneses $^{60}$, não aplicou quaisquer sanções. Naquele mesmo ano o Japão e a Alemanha se retiraram da Liga das Nações. O Japão levaria adiante seu imperialismo regional ${ }^{61}$.

\footnotetext{
${ }^{54}$ Ver Reischauer, 1971, p.151-4.

${ }^{55}$ Ver Henshall, op. cit., p.157.

${ }^{56}$ Ver Cervo, loc. cit.

${ }^{57}$ Ver Reischauer, op. cit., p.179.

${ }^{58}$ Ver Henshall, 2004, p.158-9.

${ }^{59}$ Ver Cervo, 2007, p.150.

${ }^{60}$ Ver Henshall, op. cit., p.159.

${ }^{61}$ Ver Cervo, loc. cit.
} 


\subsection{A II GUERRA MUNDIAL (1939-1945)}

A partir da década de 30, era cada vez mais evidente o aumento do controle dos militares sobre o governo e deste sobre a indústria. Depois de uma tentativa de golpe em fevereiro de 1936, houve um aumento no orçamento das forças armadas, a indústria pesada começou a se voltar para esforços de guerra e os ministros da Marinha e do Exército só poderiam ser almirantes e generais na ativa. Pouco tempo depois, ainda em novembro daquele ano, o Japão assina com a Alemanha o Pacto Anticomintern, ao qual a Itália juntou-se pouco tempo depois. Este era um acordo de assistência mútua, com o objetivo de trocas de informações contra a União Soviética, o inimigo comum ${ }^{62}$. O Japão beligerante havia voltado.

Edwin O. Reischauer diz que a II Guerra Mundial, a primeira realmente com abrangência global, começou com o acidente da Ponte Marco Pólo, em 7 de julho de 1937, quando o Japão entra em guerra com a China ${ }^{63}$. No episódio, tropas japonesas, estacionadas em manobra de forma legal perto de Pequim, alegam terem sido recebidos disparos de chineses. Em um mês houve uma escalada para a guerra aberta rapidamente, mas não declarada. De um lado o primeiro-ministro japonês Fumimaro Konoe e de outro, o chinês Chang Kai-Chek. Os japoneses dominam Xangai em novembro e a capital Nanquim em dezembro. Houve assassinatos em massa, torturas e pilhagens pelas tropas nipônicas e, ainda hoje, o número de mortos é contraditório, chineses alegam 340 mil e japoneses, 30 $\mathrm{mil}^{64}$.

Apesar da China não recapitular depois da queda de Nanquim, o Japão começou a se preocupar com a possível demora da campanha chinesa e um conseqüente enfraquecimento japonês diante da ameaça soviética. Esta havia declarado seu apoio à China e, em agosto de 1939, assina um pacto de não-agressão com a Alemanha. O Japão se sente traído, pois era contrário ao Pacto Anticomintern, além do mais, com a ascensão de Adolf Hitler ao poder, ele começou a disseminar a ideologia da superioridade ariana e considerar os japoneses como um "povo de segunda classe". O medo dos japoneses era da Alemanha se tornar um inimigo declarado com a possibilidade de se aliar a potências ocidentais como os EUA ${ }^{65}$.

\footnotetext{
${ }^{62}$ Ver Henshall, 2004, p.167.

${ }^{63}$ Ver Reischauer, 1971, p.204.

${ }^{64}$ Ver Henshall, op. cit., p.167-8.

${ }^{65}$ Ver Henshall, 2004, p.168.
} 
Em setembro de 1939, a II Guerra Mundial se inicia oficialmente. O Japão assina o Pacto Tripartido com Alemanha e Itália um ano depois, em setembro de 1940, acreditando que este lhe seria benéfico. $\mathrm{O}$ acordo garantiria uma ajuda mútua em caso de ataque por alguma potência ainda não envolvida na guerra da Europa ou do conflito sino-japonês, na entrelinhas era possível se ler "Estados Unidos". Outro ponto era o reconhecimento dos interesses japoneses na Ásia, o que dá confiança para que o Japão ampliasse suas conquistas naquele continente ${ }^{66}$. Por isso, quase simultaneamente, com o colapso da França, o Japão invade a Indochina francesa ${ }^{67}$. Em resposta, os Estados Unidos limita suas exportações para o Japão de combustíveis para aviões, aço e sucata de ferro, mas sem a intenção de intervir militarmente ${ }^{68}$.

Em junho de 1941, a Alemanha renega o pacto de não-agressão e ataca a União Soviética $^{69}$. No mês seguinte, em julho, o Japão amplia seu controle sobre o restante da Indochina, a fim de assegurar suas bases navais ao sul, para que pudesse invadir a Malásia e as Índias Orientais Holandesas. Em resposta, Washington juntamente com britânicos e holandeses impõem embargo de petróleo ao Japão ${ }^{70}$, e os EUA congelam bens japoneses naquele país. Na época, os japoneses precisavam importar $90 \%$ do petróleo utilizado, desse número, três quarto vinham dos Estados Unidos ${ }^{71}$. O embargo foi um duro golpe, mais eficaz que uma intervenção militar ${ }^{72}$. Seu exército e marinha eram amplamente dependentes de petróleo importado e, agora, só tinham dois anos de reservas ${ }^{73}$.

O Japão parecia sem saída, já que não era admissível terminarem a guerra com a China e cederem diversas concessões aos inimigos, não tanto pelo fator econômico, mas pelo orgulho militar e a admissão de que o programa militar para segurança econômica na região havia falhado ${ }^{74}$. Em 3 de setembro, os líderes nacionais decidem entrar em guerra contra os EUA. O primeiro-ministro Konoe, apesar de sua beligerância contra a China, defendia a diplomacia com os EUA para solucionar o embargo, porém o secretário de Estado americano, Cordell Hull, estava inflexível quanto aos japoneses se retirarem da Indochina e da China. Konoe se demitiu e em seu lugar ascende ao cargo de primeiro ministro, o ministro do Exército, o general Tojo Hideki. Em 1 de dezembro, o imperador

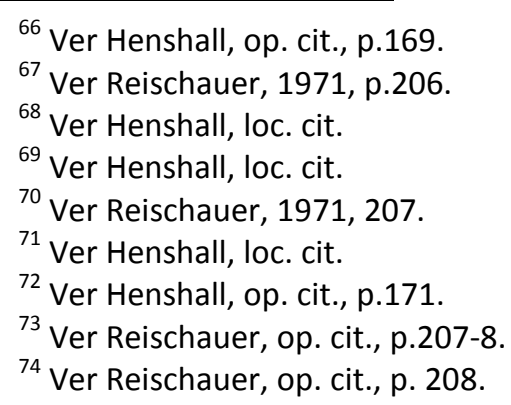


Hirohito dá seu acordo formal à guerra, acreditando que seria favorável ao Japão ${ }^{75}$. Os japoneses estavam convencidos de que os americanos não possuíam o "espírito japonês" (uma moral superior) e que não lutariam em uma guerra muito longa ${ }^{76}$.

Cerca de noventa minutos antes do ataque a Pearl Harbor, em um domingo, 7 de dezembro de 1941, o Japão ataca com sucesso uma força britânica em Kota Bharu, pois era quase certa a guerra contra a Grã-Betanha, declarando-se guerra aos EUA. Era o início da Guerra do Pacífico ${ }^{77}$.

A estratégia contra os americanos foi a mesma utilizada contra a Rùssia, em 1904, um ataque surpresa que significou uma perda americana de cerca de 4500 mortos, quatro encouraçados, 180 aviões e três destroyers. Os japoneses perderam cinco submarinos, 29 aviões e 60 homens. Apesar dos estragos consideráveis, poderia ter sido mais significativo se não tivessem se retirado prematuramente. As conseqüências imediatas foram: a entrada dos Estados Unidos na II Guerra e a suspensão da política não-intervencionista. A polêmica do episódio recai sobre o fato dos japoneses não terem avisado formalmente de suas intenções para com os americanos, nem mesmo contra os britânicos, atitude considerada falsa e traiçoeira pela América ${ }^{78}$.

O Japão, agora bastante confiante, teve uma série de êxitos, entre dezembro de 41 e o primeiro semestre de 42: poucas horas depois do ataque a Pearl Harbor uma esquadra americana foi severamente danificada em base nas Filipinas; cerca de uma semana depois a Tailândia foi ocupada; em 11 de dezembro foi a vez de Guam; em 25 de dezembro, Hong Kong se rendeu; em 23 de janeiro, a ilha de Bornéu foi controlada; em 2 de fevereiro, Manila (Filipinas) foi invadida; Cingapura em 15 de fevereiro; no fim de fevereiro, Sumatra, Bali e Timor caíram; em março, a Batávia, Rangum (Birmânia) e Java ${ }^{79}$. Em março, o general americano Douglas MacArthur é transferido por Washington das Filipinas para a Austrália, proferindo um "Voltarei", que ficara famoso ${ }^{80}$ e se tornaria verdade ao fim da II Guerra. Esses sucessos se devem em parte pelos Aliados estarem mais ocupados com a guerra na Europa, e também pela intensidade dos ataques ${ }^{81}$.

O império japonês tinha mais de oito milhões de quilômetros quadrados e, o mais importante, com riquezas petrolíferas. A sua estratégia não era a ocupação direta, inclusive

\footnotetext{
${ }^{75}$ Ver Henshall, loc. cit.

${ }^{76}$ Ver Reischauer, 1971, p.210.

${ }^{77}$ Ver Henshall, 2004, p.172.

${ }^{78}$ Ver Henshall, 2004, p. 172-3.

${ }^{79}$ Ver Henshall, op. cit., p.175 e Saraiva, 2007, p.185.

${ }^{80}$ Ver Henshall, loc. cit.

${ }^{81}$ Ibidem.
} 
com a manutenção do almirante francês Decoux na Indochina, para assegurar a paz. O objetivo era a constituição de países "satélites" a Tóquio ${ }^{82}$. Logo começaram os relatos de brutalidades com prisioneiros aliados, alto índice de mortalidade de prisioneiros nos campos japoneses, e o tratamento igualmente rígido e cruel para com os próprios soldados japoneses $^{83}$.

Mas a suposta invencibilidade do Japão começou a declinar. Em 18 de abril de 1942, 16 aviões norte-americanos B-25 bombardearam Tóquio em um ataque surpresa, sem que a defesa antiaérea japonesa conseguisse acertar um só avião americano. Ao aterrissarem na China, oito pilotos foram capturados pelos japoneses, três executados ${ }^{84} \mathrm{e}$ outros usados como cobaias nas experiências de guerra química e biológica ${ }^{85}$. Nos dias 7 e 8 de maio acontece a batalha do Mar de Coral, o Japão perde um de seus porta-aviões e os EUA também sofrem sérios danos. É a primeira vez em que os japoneses sofrem um revés, mas o mais significativo ainda aconteceria no mês seguinte, na Batalha de Midway, onde perde quatro porta-aviões, um cruzador pesado e 2000 tripulantes. O império nipônico começou a recuar, desistindo de seus planos de ocupação da Nova Caledônia, das ilhas Fiji e Samoa, da Austrália e da Nova Zelândia, além de perder Nova Guiné e Guadalcanal, neste último local sofreu uma baixa de 25 mil homens ${ }^{86}$.

Em 43, o Japão sofria de escassez de recursos, apresentando leis internas de trabalho cruéis e com racionamento rígido de comida para a sua população. Externamente os japoneses tentavam um controle cada vez mais indireto. Concederam independência nominal para alguns territórios ocupados, como a Birmânia e as Filipinas. Em 6 de novembro, assina a Declaração da Grande Ásia Oriental, se auto denominando como libertador do imperialismo ocidental, com governantes fantoches de suas conquistas: Manchúria, China, Tailândia, Birmânia, Filipinas e "Índia Livre"87.

Em julho daquele ano perde Saipan, nas Marianas, que agora poderia ser utilizado pelos EUA como base para bombardear Tóquio. Em 43, a URSS se compromete ajudar os aliados a derrotarem o Japão, tão logo a Alemanha fosse derrotada. A medida defensiva tomada pelos japoneses, na esperança de que chegassem a algum acordo de paz, foi a

\footnotetext{
${ }^{82}$ Ver Saraiva, loc. cit.

${ }^{83}$ Ver Henshall, 2004, p.177.

${ }^{84}$ Ver Henshall, op. cit., p.178.

${ }^{85}$ Ver Williams e Wallace, 1989, p.178. apud Henshall, loc. cit.

${ }^{86}$ Ver Henshall, op. cit., p.178-9.

${ }^{87}$ Ver Henshall, 2004, p.179.
} 
utilização de kamikazes (traduzido literalmente como "vento divino" e que eram "aviões suicidas") ${ }^{88}$.

Os aviões norte-americanos começaram bombardeios freqüentes à capital japonesa, culminando com dois grandes ataques na primavera de 1945 e a morte de cem mil pessoas. Apenas Quioto, dentre as grandes cidades, e outras poucas cidades menores escaparam da destruição ${ }^{89}$. Em março, Iwo Jima é tomada pelos EUA, o que facilitaria o bombardeamento ao Japão ${ }^{90}$.

Em 1 de abril de 1945, começa a invasão de Okinawa, província ao sul do arquipélago japonês. O primeiro-ministro Koiso se demite quatro dias depois e é substituído pelo almirante Suzuki Kantaro. Em 8 de maio, a Alemanha é derrotada e todos os esforços dos Aliados se voltaram para derrubarem o Japão. Em 21 de junho, Okinawa cai, com a morte de 110 mil militares japoneses, 150 mil civis, 13 mil americanos mortos e outros 40 mil feridos na Batalha de Okinawa ${ }^{91}$.

Em 26 de julho, a Declaração de Potsdam é divulgada, depois de um encontro dias antes do presidente Truman, Estaline e Churchill, com Chang Ka-Chek participando por telefone. Era exigida a rendição completa e incondicional do Japão ou a sua total e rápida aniquilação. Ao passo que os japoneses não aceitaram a Declaração ${ }^{92}$.

A decisão do uso da bomba atômica pelos Estados Unidos sobre o Japão, de acordo com Henshall, perpassa pelas seguintes possibilidades ${ }^{93}$ : minimizar os possíveis ganhos soviéticos que estavam para entrar na guerra ${ }^{94}$, o desejo de impressionar os soviéticos com a nova tecnologia atômica ou fazer experiências em um alvo real ${ }^{95}$, a possibilidade de o Japão desenvolver armas atômicas então deveriam ser os primeiros a utilizá-las ${ }^{96}$.

O fim da guerra foi rápido, uma bomba atômica foi lançada pelos americanos em 6 de agosto de 45, sobre Hiroshima, ocasionando cerca de 180 mil mortos no total, entre os com mortes imediatas e os em decorrência de efeitos da bomba nos anos seguintes. Em 9 de agosto, outra bomba é lançada sobre Nagasaki e resulta em 50 mil mortos imediatos e outros 30 mil nos anos seguintes ${ }^{97}$. Era o fim do Império do Sol Nascente.

\footnotetext{
${ }^{88}$ Ver Henshall, op. cit., p.180-1.

${ }^{89}$ Ver Reischauer, 1971, p.214.

${ }^{90}$ Ver Henshall, 2004, p.182.

${ }^{91}$ Ver Henshall, loc. cit.

${ }^{92}$ Ver Henshall, op. cit., p.183.

${ }^{93}$ Ver Henshall, loc. cit.

${ }^{94}$ Ver Alperovitz, 1965/1985 apud Henshall, loc. cit.

${ }^{95}$ Ver Sayle, 1995, p.54 apud Henshall, loc. cit.

${ }^{96}$ Ver Henshall, loc. cit.

${ }^{97}$ Ver Henshall, loc. cit.
} 
Como visto neste capítulo, foi uma nação que aprendeu com os ocidentais novas tecnologias, as adaptou e conseguiu utilizá-las em benefício próprio. O que pôde ser percebido foi que o Japão expansionista acabou por criar diversas inimizades na região, pelos mais variados motivos. E foram essas as raízes para seus problemas e vantagens no futuro. 


\section{O FIM DA SEGUNDA GUERRA MUNDIAL E A DESMILITARIZAÇÃO DO JAPÃO}

As principais conseqüências enfrentadas pelo Japão expansionista, enquanto perdedor da II Guerra Mundial, são descritas neste capítulo. O objetivo deste trabalho perpassa em saber como e porquê a nação japonesa sofreu a desmilitarização forçada, por isso a abordagem deste capítulo na nova constituição japonesa redigida pelos Estados Unidos e que permanece inalterada até hoje.

O desfecho da Guerra do Pacífico acontece em 1945, quando os Estados Unidos lançam duas bombas atômicas no Japão, a primeira em Hiroshima, no dia 6 de agosto, e três dias depois em Nagasaki. No dia 8, a União Soviética revogaria o Tratado de Neutralidade, declarando guerra ao Japão e enviando tropas no dia seguinte para a Manchúria, a Coréia e a Ilha Sacalina. A série de eventos que se segue são conseqüências de guerra, pois poucos dias depois, no dia 14, o governo aceita a Declaração de Potsdam e no dia 15 , o imperador Hirohito ${ }^{98}$ faz sua primeira transmissão via rádio ao seu povo, anunciando o fim da guerra e a rendição incondicional das forças japonesas. Cerca de 500 militares, diversos de alta patente, cometeram o suicídio para não se oporem ao imperador $^{99}$. No dia 2 de setembro, de acordo com a Declaração de Potsdam e a Initial Post-Surrender Policy Directive for Japan ${ }^{100}$, a bordo do navio de guerra norte-americano, Missouri, na baía de Tóquio, é assinada a Ata de Rendição, finalizando formalmente a Guerra do Pacífico.

Ao fim de agosto as tropas aliadas já chegavam ao Japão e, oficialmente, o período de Ocupação começou após a rendição assinada no início de setembro. Apesar de ser uma ação conjunta dos Aliados, que formaram um Conselho Aliado (Estados Unidos, GrãBretanha, União Soviética e China) e uma Comissão do Extremo Oriente (com os 11 países vitoriosos), na prática os americanos atuaram praticamente sozinhos com o general Douglas MacArthur no cargo de Comandante Supremo das Forças Aliadas (CSFA), como

\footnotetext{
${ }^{98}$ As eras no Japão moderno são designadas de acordo com os imperadores, um novo imperador significa uma nova era. Após a sua morte, no Japão, o imperador é sempre referido pelo nome da era em que reinou. No caso de Hirohito, imperador desde 25 de dezembro de 1926 até a sua morte em 7 de janeiro de 1989, o seu reinado foi batizado de Showa, ou seja, "Paz Ilustre". Ver Henshall, 2004, p.156 e Inoue, 1991, p.160.

${ }^{99}$ Ver Henshall, op. cit., p.184.

${ }^{100}$ Ver Welfield, 1988, p.61.
} 
diz Henshall ${ }^{101}$. Os objetivos iniciais eram a desmilitarização e democratização do país mas, na verdade, os EUA pretendiam prevenir o Japão de se emergir novamente como um rival com potencial industrial militar. Além do mais, Washington já preparava o futuro japonês pós-guerra desde o ataque a Pearl Harbor, em 1942, incluindo o ensino da língua japonesa para diversos militares e prevendo os possíveis problemas administrativos naquele país ${ }^{102}$.

“A desmilitarização foi o primeiro passo do ambicioso programa 'conjunto' MacArthur-Washington de construir um novo Japão. Com esta finalidade, o Exército e a Marinha foram desmobilizados em poucos meses" ${ }^{103}$. Essa seria apenas a primeira de muitas medidas tomadas contra o Japão: os territórios conquistados em seu expansionismo lhes foram tomados, retornando assim a uma situação semelhante a pré-Guerra SinoJaponesa ${ }^{104}$; às nações vítimas foi obrigado pagar indenizações; armamentos e equipamentos de guerras foram divididos entre os Aliados ou destruídos, incluindo seus aceleradores de partículas; 700 mil cidadãos foram escrutinados e outros 200 mil foram "saneados" de seus cargos entre 46 e 48 e, no mesmo período, aconteceu o Julgamento de Crimes de Guerra de Tóquio, realizado pelo Tribunal Militar do Extremo Oriente (formado pelas 11 nações consideradas vitoriosas no pós-Guerra). Foram julgados e condenados 25 homens, dos quais sete, incluindo o general Hideki Tojo e o ex-primeiro-ministro Keki Hirota (o único civil julgado), foram condenados à forca. Outros tribunais locais em Cingapura, nas Filipinas e Hong Kong condenaram outros cinco mil japoneses sob acusação dos mais diversos crimes, dos quais 900 foram executados ${ }^{105}$.

Um dos itens mais controversos sobre o Japão pós-Guerra foi que destino dar a instituição imperial e ao seu imperador. Apesar do Departamento de Defesa americano ter realizado um estudo dois anos antes, sob o título "Status of the Japanese Emperor", alegando que o sistema imperial poderia ser utilizado pelos Estados Unidos para possíveis mudanças políticas naquele país, ao fim da Segunda Grande Guerra não se tinha um posicionamento claro sobre o que fazer em relação ao Imperador Hirohito ${ }^{106}$. Com a

${ }^{101}$ Ver Welfield, 1988, p.197-8.

102 Em fevereiro de 1942, foi criada Advisory Committee on Postwar Forign Policy no Departamento de Estado Americano e, em dezembro de 44, State-War-Navy Co-ordinating Committee foi criado para políticas de ocupação na Alemanha, na Itália e no Japão. Apesar das idéias do general MacArthur serem tardias às de Washington, se provaram bastantes semelhantes durante o período de Ocupação. Ver Henshall, 2004, p.199; Reischauer, 1971, p. 222 e Ibidem, p.26.

${ }^{103}$ Ver Henshall, op. cit., p.200.

${ }^{104}$ Ver capítulo 1.

105 Ibidem, p.200-2.

${ }^{106}$ Ver Inoue, 1991, p.160. 
chegada do general MacArthur, em 30 de agosto de 1945, o destino do imperador foi decidido. Para Henshall, "o grande salvador de Hirohito foi MacArthur" ${ }^{107}$. Explica-se aqui o fato de, em 6 de outubro de 1945, o State-War-Navy Coordinating Committee (SWNCC) subcommittee on the Far East ter concluído seu relatório dizendo que o imperador deveria ser preso, julgado e punido como criminoso de guerra. Ao general MacArthur, apesar da decisão do SWNCC ser contrária a do Departamento de Estado, coube a responsabilidade de recolher as evidências e enviá-las, juntamente com o seu parecer sobre quando começar o processo contra o imperador Showa, à Junta dos Chefes do Estado-Maior ${ }^{108}$.

No dia 27 de setembro daquele ano, Hirohito encontrou-se com o general na embaixada americana, se oferecendo para ser julgado como o único responsável pelas decisões políticas e militares que conduziram os japoneses à guerra ${ }^{109}$. Após este encontro, o CSFA se convenceu que o imperador deveria ser mantido por sua utilidade e, também, por ter se impressionado com sua atitude como indivíduo ${ }^{110}$.

Quando o general envia o memorando à Junta dos Chefes do Estado-Maior, sua defesa a manutenção do imperador inocente foi enfática, inclusive com ressalvas às possíveis consequiências danosas aos planos dos Aliados ${ }^{111}$. Não é claro até onde MacArthur conseguiu afetar as intenções dos americanos ${ }^{112}$, mas o que se segue fica subentendido a influência do general. Hirohito não apenas não foi a julgamento por crimes de guerra e possivelmente condenado à morte, como permaneceu no trono ${ }^{113}$. Mesmo assim, na tentativa de evitar qualquer possível insurgência militar nipônica, em dezembro de 1945, Washington publica a Diretiva sobre o Xintoísmo, para desmantelar o Estado xintoísta, já que o xintoísmo havia sido declarado uma religião e, portanto, deveria estar separada do Estado; e também publica a Declaração de Humanidade, que modificava a

${ }^{107}$ Ver Henshall, op. cit., p.203.

${ }^{108}$ Ver Ward, 1987 apud Inoue, loc. cit.

${ }^{109}$ As palavras do imperador Showa ao general MacArthur em seu encontro: "I come to you, General MacArthur, to offer myself to the judgment of the powers you represent as the one to bear sole responsibility for every political and military decision made by my people in the conduct of war". Ver Inoue, 1991, p. 162. Ao passo que MacArthur escreveu em seu livro anos mais tarde: "A tremendous impression swept me. This Courageous assumption of a responsibility implicit with death, a responsibility clearly belied by facts of which I was fully aware, moved me to the very narrow of my bones. He was an Emperor by inherent birth, but in that instant I knew I faced the First Gentleman of Japan in his own right". Ver MacArthur, 1964, p.288 apud Inoue, loc. cit.

${ }^{110}$ Ver Inoue, 1991, p.163.

${ }^{111}$ Ver Henshall, 2004, p.203.

${ }^{112}$ Ver Inoue, op. cit., p.164.

${ }^{113}$ Ver Henshall, loc. cit. 
imagem divina do imperador, de modo que o povo não mais fosse obrigado a reverenciá-lo como um deus-imperador ${ }^{114}$.

Por fim, a mais significativa conquista da desmilitarização foi a nova constituição $^{115}$, promulgada em novembro de 1946, que permanece inalterada até os dias atuais como símbolo, ao menos para o exterior, da democratização japonesa ${ }^{116}$. Além da consolidação da Diretiva sobre o Xintoísmo e da Declaração de Humanidade, foi adicionado a conhecida cláusula de renúncia à guerra, entre outros pontos. Aqui o texto do artigo IX da Constituição:

Aspirando sinceramente a uma paz internacional baseada na justiça e na ordem, o povo japonês renuncia para sempre à Guerra como direito soberano da nação e à ameaça e ao uso da força como meio de resolver questões internacionais.

Para cumprir o objetivo do parágrafo precedente, nunca mais serão mantidas forças terrestres, navais ou aéreas nem quaisquer outros meios de fazer a Guerra. Não será reconhecido o direito de beligerância por parte do Estado ${ }^{117}$.

\subsection{A CONSTITUIÇÃO "MACARTHISTA"}

A revisão constitucional que se seguiu no pós-Guerra fazia parte dos planos iniciais dos americanos em democratizar o Japão, pois acreditavam ter aquela uma nação um governo despótico que privava seus cidadãos de direitos e liberdades. Segundo os EUA, a Constituição Meiji, promulgada em $1889^{118}$, não protegia suficientemente o povo japonês dos excessos de seus governantes. Ainda assim, em princípio, deixaram que os japoneses esboçassem sua nova constituição ${ }^{119}$.

Aparentemente a idéia original de uma constituição japonesa pacifista foi ou do então Primeiro-Ministro no período que seguiu a rendição, o Barão Kijūrō Shidehara, ou

\footnotetext{
114 Ibidem, p.204.

115 Ibidem, p.201.

116 Ibidem, p.205.

${ }^{117}$ Ibidem, p.201. No original: “(1) 日本国民は、正義と秩序を基調とする国際平和を誠 実に希
} 求し、国権の発動たる戦争と、武力による威嚇又は武力の行使は、国際紛争を解決する手段とし ては、永久にこれを放棄する。(2) 前項の目的を達するため、陸海空軍その他の戦力は、これを保 持しない。国の交戦権は、これを認めない。”Ver Inoue, 1991, p.274.

\footnotetext{
${ }^{118}$ Ver capítulo 2

${ }^{119}$ Ver Inoue, 1991, p.1.
} 
do próprio general Douglas MacArthur ${ }^{120}$, que alegou mais tarde ter a idéia sugerida pelo Barão $^{121}$.

Em 25 de outubro de 1945, o governo japonês anunciou a criação do Constitutional Problem Investigation Committee, com o objetivo de revisar a Constituição Meiji e conduzido por Jōji Matsumoto, ministro de estado e ex-professor de direito da Universidade Imperial de Tóquio, indicado por Shidehara. De fato o governo sabia que aquele era um assunto importante, mas levaria mais tempo do que aquele dado pelos americanos, além do mais não havia a real intenção de uma reforma profunda na constituição anterior. É preciso compreender que naquele momento outros problemas mais imediatos também necessitavam atenção, como a fome de seu povo e a tentativa de lidar com as condições caóticas do imediato pós-Guerra. Ao fim da Segunda Guerra dois milhões de cidadãos japoneses haviam sido mortos, do quais cerca um terço era civil ${ }^{122} ; 15$ milhões estavam desabrigados ${ }^{123}$; e a repatriação de mais de seis milhões de soldados desarmados e civis, que agora voltavam para casa, começou em setembro de 45 e teve seu auge na metade do ano seguinte, quando cerca de 200 mil chegavam a cada semana ${ }^{124}$. Com a forçada revisão constitucional, os japoneses estavam dispostos a mudar certas cláusulas da antiga constituição que foram invalidadas pela rendição, mas tentando manter o que sobrara da antiga ordem ${ }^{125}$.

O assessor político de MacArthur, George Atchenson, parecia preocupado com a falta de supervisão norte-americana e os possíveis resultados aos quais os japoneses chegariam, fazendo uma transmissão de rádio pedindo aconselhamento ao Secretário de Estado dos EUA, em 4 de outubro. No dia 16, recebeu alguns pontos a serem incluídos na nova constituição japonesa, porém o general não transmitiu a informação aos japoneses. No dia 13 de dezembro, o Departamento de Estado envia a versão preliminar da Reform of the Japanese Government, que acaba servindo como base para a revisão constitucional japonesa, cujo texto final foi enviado ao general no dia 11 de janeiro de 46, mesmo assim, MacArthur mantinha a mesma estratégia de não informar o governo nipônico ${ }^{126}$.

Enquanto isso, o comitê de Matsumoto trabalhava às portas fechadas também, e sem avisar aos norte-americanos preparou duas versões, uma mais conservadora e de

\footnotetext{
${ }^{120}$ Ver Welfield, 1988, p.63.

${ }^{121}$ Ver Military Situation, p.223 apud Welfield, op. cit., p.63.

${ }^{122}$ Ver Inoue, op. cit., p.10.

${ }^{123}$ Ver James, 1985, 3:5 apud Inoue, ibidem, p.10.

${ }^{124}$ Ver U.S. Army, 1966, p.149 apud Inoue, ibidem, p.10.

${ }^{125}$ Ver Inoue, ibidem, p.10.

${ }^{126}$ Ver Inoue, op. cit., p.11.
} 
autoria de Matsumoto e outra mais liberal, realizada por jovens membros do comitê. $\mathrm{O}$ interesse na nova constituição crescia várias sugestões eram publicadas pelos jornais, os partidos Liberal e Comunista vieram a público com as suas idéias, além de outras versões preparadas por diversas instituições. Porém, no dia 1 de fevereiro, acontece o derradeiro fim da proposta preparada por Matsumoto. O jornal de maior circulação no Japão, o Mainichi Shimbun, publica em sua primeira página o que seria praticamente a versão final da constituição de Matsumoto, no qual 39 dos 76 artigos haviam sido retirados na Constituição Meiji e, ainda, proclamava o Japão uma monarquia, cujo soberano seria o imperador. O governo japonês declarou que aquela versão nada tinha a ver com a versão publicada pelo comitê, enviada aos norte-americanos no dia 8 de fevereiro. Mas era tarde demais, MacArthur já havia se decidido e consultou diretamente o chefe do Government Section, Courtney Whitney, sobre a possibilidade americana na intervenção na revisão constitucional. A resposta não poderia ser mais vantajosa, pois sua única restrição era sobre a remoção do imperador. O general tinha carta branca para a reforma ${ }^{127}$.

Na manhã de domingo do dia 3 de fevereiro, MacArthur instruiu Whitney a preparar uma versão preliminar da nova constituição nipônica, de modo que incorporassem três princípios básicos: limitação da monarquia, renúncia à guerra e abolição ao feudalismo. Apenas uma semana depois, o comitê americano terminou a primeira versão do que viria a ser a nova Constituição do Japão, com 92 artigos. E, às 10 horas do dia 13, Whitney e três outros membros de seu comitê apresentaram o esboço da nova constituição ao Ministro dos Negócios Estrangeiros, Shigeru Yoshida, na companhia de Jōji Matsumoto e outros dois assistentes do ministério. Os americanos alegaram que a versão enviada pelos japoneses era inaceitável ao Comandante Supremo, portanto, com o objetivo de proteger o povo de injustiças e controle arbitrário cometido no passado, apresentavam os princípios que o Japão necessitava naquele momento ${ }^{128}$. Inclusive, por conta própria, Whitney disse aos japoneses que o próprio MacArthur levaria a Constituição ao povo, se o governo nipônico não o fizesse ${ }^{129}$. De fato os japoneses não esperavam isso, e foram realmente surpreendidos

\footnotetext{
${ }^{127}$ Ibidem, p.12-6.

${ }^{128}$ As palavras de Whitney ao entregar a versão preliminar da nova constituição: "The draft of the constitutional revision, which you submitted to us the other day, is wholly unacceptable to the Supreme Commander, however, being fully conscious of the desperate need of the people of Japan for a liberal and enlightened Constitution that will defend them from the injustices of the arbitrary control of the past, has approved this document and directed that I present to you as one embodying the principles which in his opinion the situation in Japan demands. In order that you gentlemen may understand fully the contents of the document to which I will hereafter further allude, my officers and I will withdraw to permit you freely to examine and discuss the same". Ver Takayanagi et al., 1972, 1:322 apud Inoue, ibidem, p.12-6.

${ }^{129}$ Ver Inoue, 1991, p.16-8
} 
com a versão preparada pelos americanos ${ }^{130}$. Whitney explica que MacArthur teve pressa em agir, pois estava tentando proteger o imperador Hirohito de ser julgado por crimes de guerra $^{131}$.

As negociações entre os dois governos perduraram pelos próximos oito meses, sendo promulgada em 3 de novembro de 1946, entrando em vigor em 3 de maio de $1947^{132}$.

Mais tarde algumas questões foram levantadas sobre o processo na realização da Constituição, como o real conhecimento dos militares norte-americanos acerca do Japão, ou mesmo de constituições. O chefe do comitê e responsável pelo esboço, o coronel Charles L. Kades admitiu que seu conhecimento sobre aquele país era "nulo" ${ }^{133}$. Kyoko Inoue argumenta que a própria Constituição dos EUA fora usada como base e que os principais articuladores norte-americanos responsáveis pela reforma constitucional eram New Dealers. A autora ainda questiona o conceito de democracia universal para os americanos como sendo a democracia no modelo dos EUA, ademais, sendo imposta a outra nação não compreendendo que a mesma pudesse negar essa democracia se lhe fosse oferecida a opção de escolha ${ }^{134}$.

A democracia relativa dos americanos pode ser notada ao serem realizadas as eleições para o novo parlamento, em abril de 46. O Barão Shidehara perdeu seu posto para Ichiro Hatoyama, presidente do recém-criado Partido Liberal do Japão, mas suas atividades antes da Guerra levaram ao CSFA não aceitá-lo. A substituição da chefia do partido e, conseqüente posse como primeiro-ministro, foi concedida a Shigeru Yoshida ${ }^{135}$.

Kenneth Henshall enumera os pontos-chave da nova Constituição do Japão, chamando atenção à questão da igualdade de sexos, que causou intenso debate, mas afinal foi $\operatorname{aprovada}^{136}$ :

- o imperado era considerado símbolo do povo;

- a soberania pertencia, por direito, ao povo;

- renúncia à guerra e à manutenção de forças armadas;

- igualdade dos sexos;

\footnotetext{
${ }^{130}$ Para saber mais sobre a reação japonesa a entrega do primeiro esboço da constituição ver Takayanagi et al., 1972, 1:324,326 apud Inoue, op. cit., loc. cit.

${ }^{131}$ Ibidem, 1:326, 328.

${ }^{132} \mathrm{O}$ dia 3 de maior foi declarado feriado nacional, Constitutional Memorial Day. Ver Inoue, op. cit., p.1, 36.

${ }^{133}$ Ver Henshall, 2004, p.205.

${ }^{134}$ Ver Inoue, 1991, p.74-5.

${ }^{135}$ Ver Henshall, op. cit., p.206.

${ }^{136}$ Ibidem, p.206.
} 
- garantia dos direitos humanos em geral, nomeadamente do "direito à vida, liberdade e procura da felicidade";

- garantia do direito de reunião, pensamento, crença (incluindo de religião) e expressão;

- direito de voto concedido a todos os adultos de mais de 20 anos;

- separação da religião e do Estado;

- garantia do direito dos trabalhadores a organizarem-se e a negociarem coletivamente, bem como de padrões laborais mínimos;

- instituição da educação livre e igual;

- abolição dos títulos nobiliárquicos;

- instituição de um poder judicial independente;

- cláusula de revisão da constituição (por maioria de dois terços em ambas as Câmaras e apoio majoritário do povo através de referendo) ${ }^{137}$.

O Japão tinha agora a sua nova constituição, mesmo que no fundo tenha sido uma imposição norte-americana ao perdedor da Segunda Grande Guerra. A desmilitarização descrita no artigo 9 (renúncia à guerra) foi, contudo, a maior condenação a um país até pouco tempo militarista.

${ }^{137}$ Ibidem, p.207. 


\section{A TENTATIVA DE REMILITARIZAÇÃO NO INÍCIO DO SÉCULO XXI}

Neste terceiro capítulo objetiva-se esclarecer como se encontra a defesa japonesa hoje, incluindo as Forças de Autodefesa do Japão (Dietai) e as Forças dos Estados Unidos no Japão. Além disso, serão levantados alguns pontos que levariam a uma possível tentativa de remilitarização do Japão no início do século XXI, especialmente com a entrada no poder do primeiro-ministro Junichiro Koizumi (2001 a 2006), polêmico por visitas anuais ao Santuário de Yasukuni, local que honra vários condenados de guerra, o que causou protestos em países vizinhos como China e Coréia do Sul. Em 2006 e 2007, sobe ao poder Shinzo Abe, o mais jovem e o primeiro governante nascido no pós-guerra, com a promessa de mudanças na constituição pacifista do país. Porém com a renúncia de Abe, antes de completar um ano de governo, e a eleição do veterano Yasuo Fukuda para o cargo, em setembro de 2007, o futuro da revisão constitucional parece ter saído dos planos do governo japonês.

\subsection{UM BREVE HISTÓRICO}

Primeiramente, é preciso esclarecer que o Japão não ficou inteiramente desprotegido militarmente em todos esses anos de pós-guerra, dependendo exclusivamente das bases norte-americanas em seu território para sua defesa. Em novembro de 1945, há a dissolução do Exército e da Marinha Imperial do Japão, apesar de contrária às expectativas dos EUA sobre a manutenção da desmilitarização japonesa, uma série de eventos força os americanos a repensarem sua política. No final da década de 40, os comunistas vencem na China, as relações entre Pequim e Moscou estão em ascensão, o sudeste asiático está instável e os EUA decidem intervir na guerra civil da Coréia, isso tudo leva o general MacArthur ordenar ao governo japonês a criação da Força Policial de Reserva (Keisatsu Yobitai), com 75 mil homens, e da Força Marítima de Segurança, com 8,5 mil homens ${ }^{138}$.

Em 1951, o Acordo de Assistência de Segurança Mútua entre Japão e EUA é assinado, sem que houvesse um consulta de ambos os lados, os Estados Unidos

${ }^{138}$ Ver Welfield, 1988, p.61 72. 
permaneceria como defensor do Japão até que o mesmo pudesse se defender sozinho ${ }^{139}$. Isso permitiu formalmente que bases norte-americanas permanecessem em território japonês. Não demoraria muito para que, em 1954, fossem estabelecidas a Lei das Forças de Autodefesa e, em 56, a Lei sobre o Conselho de Defesa Nacional, que definiram os procedimentos políticos e a estrutura das forças de defesa, sempre baseados no controle civil. As novas forças de defesa eram bastante diferentes do Exército e da Marinha Imperial, cujos líderes agiam independentemente do Gabinete (Executivo), além dos ministros da Guerra e da Marinha nomeados sempre serem generais e almirantes ${ }^{140}$.

Antes mesmo do Tratado de Paz de São Francisco, o governo americano mantinha recomendações de que houvesse uma integração completa, política, econômica, militar e psicológica, dentro do sistema de aliança anticomunista global americana. Os EUA tinham particular interesse no relacionamento do Japão com outros países asiáticos nãocomunistas e seu papel militar na região ${ }^{141}$. O Conselho de Segurança Nacional americano recomendava a contínua promoção na recuperação econômica do Japão e mais, ajuda no desenvolvimento de forças militares apropriadas e em equipamento militar de baixo custo para uso próprio e em outros países não-comunistas da Ásia, tomar todas as medidas concretas para assegurar a entrada como membro nas Nações Unidas e participação na segurança regional, estabelecer programas psicológicos apropriados na intenção de orientar os japoneses a um mundo livre e longe do comunismo ${ }^{142}$.

Em 8 de setembro de 1951, o Tratado de Paz de São Francisco é assinado pelo Japão e outras 48 nações. Nele foi formalmente confirmado que o Japão perderia suas antigas colônias, incluindo Taiwan e a Coréia; o sul da ilha de Sacalina e as ilhas Curilas foram atribuídas à União Soviética (motivo de disputas e discussões até hoje); as ilhas que formam a província de Okinawa foram colocadas sob tutela dos EUA, assim como as ilhas Bonin (Ogasawara) - esta devolvida em 1968 e aquelas em 1972. Okinawa ainda mantém a maior parte das bases americanas hoje no Japão. Os japoneses ainda acordaram nos termos do tratado em pagar indenizações, atenuadas por uma cláusula que as vinculava ao estado da economia do país no período, o que favoreceu bastante os nipônicos. O tratado também limitou os gastos anuais com sua defesa a 1\% de seu PIB, o que ao longo dos anos

\footnotetext{
${ }^{139}$ Ver Katzenstein, 1996, p.146.

140 Ibidem, p.61.

141 Ibidem, p.88.

142 United States Department of Defense, 1945-52, p.434-5 apud Welfield, loc. cit.
} 
provou ter sido essa outra vantagem econômica, já que outras nações gastam entre $6 \%$ e $7 \%$ em tempos de paz $^{143}$.

Em 19 de janeiro de 1960, um novo pacto é assinado na intenção de revisar o pacto de 51, o Tratado de Segurança e Cooperação Mútua. O primeiro deixava os Estados Unidos livre para utilizar as suas bases no Japão em favor da manutenção da paz mundial e da segurança no extremo oriente e no Japão; oferecendo a chance do governo japonês pedir ajuda para acabar com revoltas internas de larga escala. Na realidade, o tratado desigual e sem data para um fim fazia do Japão um protetorado americano "semicolonial". Nesse novo tratado, a diferença significativa está em os EUA consultar o Japão todas as vezes que fossem utilizadas as bases americanas no Japão, além de limitar o tratado, em princípio, em dez anos ${ }^{144}$. Uma nova era nas relações nipo-americanas começavam, sendo marcada pela visita do Presidente Eisenhower ao Japão após a formalização do novo tratado, seguido anos depois de uma visita de retribuição pelo então príncipe herdeiro Akihito ${ }^{145}$.

\subsection{O MINISTÉRIO DA DEFESA DO JAPÃO HOJE}

A Agência de Defesa, criada em 1954, foi reformulada e se tornou o Ministério da Defesa, em 9 de janeiro de 2007. Dentre as novas atribuições estão a possibilidade do ministério poder propor legislações diretamente nos encontros com o gabinete (primeiroministro) e poder requisitar orçamento diretamente ao Ministério das Finanças, sem ter de passar pelo gabinete. O comandante supremo permanece o primeiro-ministro, que passará as ordens ao ministro da Defesa, de modo que permaneça o controle civil ${ }^{146}$. Há hoje Forças de Autodefesa terrestre, aérea e marítima do Japão.

Atualmente, o Ministério da Defesa do Japão esclarece que há três pontos que fundamentam o seu conceito de defesa: a Constituição do Japão e o direito de autodefesa, as bases para a política de defesa, e os acordos de segurança entre Japão e Estados Unidos.

Em primeiro lugar, a sua interpretação quanto ao artigo 9 de sua constituição, sobre a renúncia à guerra. O Japão vale-se da idéia de que há o direito de autodefesa e, para que isso seja garantido, é permitido que o país possua e mantenha um mínimo de forças

\footnotetext{
${ }^{143}$ Ver Henshall, 2004, p.216-7.

${ }^{144}$ Ver Reischauer, 1971, p.280-1.

${ }^{145}$ Ver Welfield, op. cit., p.137.

${ }^{146}$ Ver Foreign Press Center Japan, 2007, p.64.
} 
armadas, sempre orientadas apenas para a defesa. Sob este ponto de vista o governo japonês cita cinco pontos interpretados do artigo nono:

a) possessão e manutenção da capacidade de autodefesa se limitado a armamentos de defesa, não possuindo equipamentos, como bombardeiros de longo alcance;

b) há três requisitos para o exercício do direito de autodefesa quando houver um ato de agressão iminente e ilegítimo contra o Japão, não houver outra forma apropriada para repelir essa agressão, se não o uso do direito de autodefesa e, o uso de forças armadas será o mínimo necessário para que $\mathrm{o}$ ato seja repelido;

c) o alcance geográfico do exercício do direito de autodefesa não há regras ou limites apenas ao espaço territorial, aéreo e naval do Japão para que o direito de autodefesa seja colocado em prática, no entanto não é permitido o envio de tropas ao exterior já que excederia o nível mínimo necessário para a autodefesa;

d) o direito de autodefesa coletiva - de acordo com leis internacionais o Japão poderia fazer uso de forças militares com o intuito de parar um ataque a uma nação amiga, porém, isso não é admissível, pois excederia o limite do uso de forças armadas permitido no artigo 9; o direito à beligerância - apesar de estar escrito no segundo parágrafo do nono artigo, que não será reconhecido o direito à beligerância, o uso do direito mínimo de autodefesa é considerado diferente do direito de beligerância ${ }^{147}$.

Em segundo, há a "Política de Defesa Básica", adotada em 20 de maio de 1957, que serve como base para a política de defesa japonesa desde então. Para que haja a prevenção de ataques diretos e indiretos, invasões sejam repelidas e haja a manutenção de sua independência e sua paz baseando-se na democracia, certos pontos foram colocados em 57:

${ }^{147}$ Ver Japan Ministry of Defense (www.mod.go.jp/e/d_policy/dp01.html). 
1) apoiar as atividades das Nações Unidas, promovendo a colaboração internacional e se comprometendo na realização da paz mundial;

2) estabilizar as fontes de renda população, encorajar o patriotismo e, assim, estabelecer as bases necessárias para a segurança nacional;

3) construir uma real capacidade de defesa dentro do limite necessário para autodefesa, de acordo com a força e a situação nacional;

4) lidar com agressões externas baseando-se em acordos com os Estados Unidos, até que as Nações Unidas sejam capazes de cumprir sua função em parar tal agressão efetivamente no futuro. No decorrer dos anos a política de defesa japonesa manteve suas bases, porém alguns tópicos foram adicionados:

5) política de orientação defensiva exclusiva;

6) não se tornar uma potência militar;

7) adoção dos Três Princípios Não-Nucleares - não possuir, não produzir e não deixar que armas nucleares sejam trazidas ao Japão;

8) assegurar o controle civil - no caso do controle de forças militares $^{148}$.

Por último, o Acordo de Cooperação e Segurança Mútua entre Japão e Estados Unidos, assinado em 1960, permanece válido até os dias atuais e servindo como base para novos debates e acordos dentro do Comitê Consultivo de Segurança Japão-Estados Unidos (dois-mais-dois) e Aliança ${ }^{149}$.

Em 1976, o gabinete decidiu que os gastos em defesa não deveriam ultrapassar $1 \%$ do seu produto interno bruto (PNB). Porém, em 1987, este teto foi modificado, sendo substituído por um cálculo que seria ajustado de acordo com o gasto total estipulado pelo Midterm Defense Program.

${ }^{148}$ Ver Japan Ministry of Defense (www.mod.go.jp/e/d_policy/dp02.html).

${ }^{149}$ Ver Japan Ministry of Defense (www.mod.go.jp/e/d_policy/dp03.html). 
Em dezembro de 2004, o gabinete aprovou os principais pontos do novo Programa Nacional de Defesa, que servirá como base para a defesa nacional do país pelos próximos dez anos. Objetiva-se com isso, uma política de construção da força de defesa multifuncional, flexível e eficaz, para responder às novas ameaças como o terrorismo, a proliferação de armas de destruição de massa e mísseis balísticos (com trajetória prédeterminada). Houve uma diminuição de pessoal e equipamentos nas Forças de Autodefesa, passando a 155 mil homens (menos cinco mil em relação ao último remanejamento), 600 tanques (menos 300), 47 navios de escoltas (menos três), 16 submarinos (sem mudança), 260 aviões de combate (cerca de menos 40$)^{150}$. E o orçamento previsto para os anos de 2005 até 2009 teve sua primeira queda, sendo disponibilizado o valor para o período de $¥ 24.24$ trilhões, sendo que anteriormente o valor era de $¥ 25.01$ trilhões, no programa anterior $^{151}$.

Como mostrado na Tabela 1, em que são apresentados os gastos anuais em defesa pelo Japão, é possível notar uma queda de $0,3 \%$ no orçamento do ano fiscal de 2007 em relação ao ano fiscal de 2006. Dentro deste orçamento está uma assistência financeira para custear parte dos gastos das Forças Militares Americanas no Japão, ato que começou em 1978, estipulando um acordo bilateral na qual, dentre outras questões, o governo japonês pagaria o salário de cidadãos japoneses que trabalhassem nas bases americanas. $\mathrm{O}$ orçamento para isso teve um acréscimo de $¥ 2.9$ bilhões no ano de 2007 , passando a ser de $¥ 218$ bilhões para esse fim $^{152}$.

Como comparação dos gastos em defesa, na Tabela 2 é possível notar que mesmo com a restrição de gatos anuais, o Japão é o terceiro país do mundo com maior orçamento para esse setor, ficando atrás apenas dos EUA e o Reino Unido.

\footnotetext{
${ }^{150}$ Ver Foreign Press Center Japan, 2007, p.64-9.

151 Ibidem, p.64.

152 Ibidem, p.69.
} 
Tabela 1

Gastos anuais em defesa de acordo com o orçamento inicial

\begin{tabular}{|r|r|r|r|r|}
\hline Ano & $\begin{array}{r}\text { Gastos } \\
\text { (em billhões } ¥)\end{array}$ & $\begin{array}{r}\text { Crescimento sobre o ano } \\
\text { anterior }(\%)\end{array}$ & $\begin{array}{r}\text { Parte do } \\
\text { orçamento }\end{array}$ & $\begin{array}{r}\text { Parte do PIB1 } \\
(\%)\end{array}$ \\
\hline $\mathbf{1 9 6 5}$ & 301 & 9.6 & 8.2 & $\mathbf{1 . 0 7}$ \\
\hline $\mathbf{1 9 7 5}$ & 1,327 & 21.4 & 6.2 & $\mathbf{0 . 8 4}$ \\
\hline $\mathbf{1 9 8 5}$ & 3,137 & 6.9 & 6.0 & $\mathbf{0 . 9 9 7}$ \\
\hline $\mathbf{1 9 9 0}$ & 4,159 & 6.1 & 6.3 & $\mathbf{0 . 9 9 7}$ \\
\hline $\mathbf{1 9 9 5}$ & 4,724 & 0.9 & 6.7 & $\mathbf{0 . 9 5 9}$ \\
\hline $\mathbf{2 0 0 0}$ & 4,936 & $0.1^{2}$ & 5.8 & $\mathbf{0 . 9 8 9}$ \\
\hline $\mathbf{2 0 0 1}$ & 4,955 & $0.4^{2}$ & 6.0 & $\mathbf{0 . 9 5 6}$ \\
\hline $\mathbf{2 0 0 2}$ & 4,956 & $0.0^{2}$ & 6.1 & $\mathbf{0 . 9 9 9}$ \\
\hline $\mathbf{2 0 0 3}$ & 4,953 & $-0.1^{2}$ & 6.1 & $\mathbf{0 . 9 9 3}$ \\
\hline $\mathbf{2 0 0 4}$ & 4,903 & $-1.0^{2}$ & 6.0 & $\mathbf{0 . 9 7 9}$ \\
\hline $\mathbf{2 0 0 5}$ & 4,856 & $-1.0^{2}$ & 5.9 & $\mathbf{0 . 9 4 9}$ \\
\hline $\mathbf{2 0 0 6}$ & $\mathbf{4 , 8 1 4}$ & $\mathbf{- 0 . 9}^{2}$ & $\mathbf{6 . 0}$ & $\mathbf{0 . 9 3 7}$ \\
\hline
\end{tabular}

Fonte: Agência de Defesa, Boei hakusho (Defesa do Japão), 2006.

1. As figuras acima através 1990 são representadas em relação ao PNB.

2. Incluem os custos dos projetos do Special Action Committee em Okinawa (SACO)

Tabela 2

Comparação dos gastos na defesa nacional

\begin{tabular}{|l|r|r|r|}
\hline País & Gasto total (US\$ milhão) & Gasto per capita (US\$) & Parte do PIB (\%) \\
\hline EUA & $\mathbf{4 3 6 , 5 2 1}$ & $\mathbf{1 , 4 7 0}$ & $\mathbf{3 . 8}$ \\
\hline Reino Unido & 47,696 & 803 & $\mathbf{2 . 5}$ \\
\hline Japão & $\mathbf{3 6 , 6 6 5}$ & $\mathbf{2 8 6}$ & $\mathbf{1 . 0}$ \\
\hline França & 36,123 & 598 & $\mathbf{2 . 0}$ \\
\hline Alemanha & $\mathbf{2 5 , 8 2 5}$ & $\mathbf{3 1 3}$ & $\mathbf{1 . 1}$ \\
\hline
\end{tabular}

Fonte: Agência de Defesa, Boei hakusho (Defesa do Japão), 2006.

Nota: Os gastos de defesa são baseados nas indicações de orçamentos, relatórios de defesa e outros documentos de cada país. Conversão das moedas adotado: $\$ 1=¥ 133=£ 0.619=$ 0.939 euro [Alemanha] $=0.897$ euro [França $]$.

Dentre as medidas de defesa para responder situações diversas de modo apropriado, em junho de 2003, a Dieta (parlamento) decretou três planos de contingência em resposta a ataques armados, incluindo a Law Concerning Measures to Ensure National Independence and Security in a Situation of Armed Attack. Em junho do ano seguinte, outros sete planos de contingência foram aprovados pela Dieta, com a inclusão daqueles para proteger seus cidadãos e dando prioridade de uso de aeroportos e navios às Forças de Autodefesa ${ }^{153}$.

Em maio de 2006, o Comitê Consultivo de Segurança Japão-Estados Unidos chegaram a um acordo sobre o realinhamento das forças americanas no Japão, com o 
Japan-US Roadmap for Realignment Implementation. Dentre os tópicos abordados, ganham destaque a construção de uma instalação substituta para a Base Aérea de Futenma e a transferência de oito mil fuzileiros de Okinawa para Guam até $2014^{154}$.

Hoje, $75 \%$ das instalações militares norte-americanas no Japão se encontram em Okinawa $^{155}$. Ao fim do período de ocupação em 1952, havia cerca de 3.800 instalações militares norte-americanas no Japão, em 1970 houve uma significativa diminuição para 125 bases $^{156}$. Em 2004, o relatório do Departamento de Defasa dos EUA relata 158 instalações ${ }^{157}$, diminuindo para 111 em $2005^{158}$, se mantendo com o mesmo número em $2006^{159}$, mas subindo novamente para 130 , em $2007^{160}$.

Na Tabela 3, a seguir, há o detalhamento das forças americanas em solo japonês nos anos de 2000 e 2006, assim permitindo notar que há uma diminuição no contingente norte-americano neste período. E na tabela 4 há uma comparação do mesmo período do contingente das Forças de Autodefesa japonesas, lembrando que a diminuição de pessoal e equipamentos previstos no novo Programa Nacional de Defesa tem como objetivo os próximos dez anos.

Tabela 3

Forças militares dos EUA no Japão (em terra)

\begin{tabular}{|l|r|r|} 
& \multicolumn{3}{|c|}{ Ano de 2000 } & Ano de 2006 \\
\hline Exército & 1.787 & $\mathbf{1 . 6 7 0}$ \\
\hline Marinha & 5.496 & $\mathbf{6 . 3 8 0}$ \\
\hline Fuzileiros navais & 19.682 & $\mathbf{1 5 . 8 5 0}$ \\
\hline Força aérea & 13.194 & $\mathbf{1 3 . 0 9 0}$ \\
\hline Total & $\mathbf{4 0 . 1 5 9}$ & $\mathbf{3 6 . 9 6 0}$ \\
\hline
\end{tabular}

Fonte: Força dos Estados Unidos, Japão.

Nota: Em outubro de 2006

${ }^{154}$ Ver Foreign Press Center Japan, op. cit., p.65. Para mais detalhes sobre o Japan-US Roadmap for Realignment Implementation ver Japan Ministry of Defense (www.mod.go.jp/e/d_policy/dp13.html).

${ }^{155}$ Ver Foreign Press Center Japan, loc. cit.

${ }^{156}$ Ver Greene, 1975, p.47.

${ }^{157}$ Ver U.S. Department of Defense (www.defenselink.mil/pubs/20040910_2004BaseStructureReport.pdf).

${ }^{158}$ Ver U.S. Department of Defense (www.defenselink.mil/pubs/20050527_2005BSR.pdf).

${ }^{159}$ Ver U.S. Department of Defense (www.defenselink.mil/pubs/BSR_2006_Baseline.pdf).

${ }^{160}$ Ver U.S. Department of Defense (www.defenselink.mil/pubs/BSR_2007_Baseline.pdf). 
Tabela 4

Potencial militar das Forças de Autodefesa

\begin{tabular}{|l|l|r|r|}
\hline \multirow{3}{*}{ Força } & Ano de 2000 & Ano de 2006 \\
& Pessoal & 148.557 & $\mathbf{1 4 8 . 3 0 2}$ \\
\cline { 2 - 4 } & Tanque & 1.070 & $\mathbf{9 5 0}$ \\
\cline { 2 - 4 } & Veículo blindado & 690 & $\mathbf{9 5 0}$ \\
\hline \multirow{4}{*}{ Marítima } & Pessoal & 42.655 & $\mathbf{4 4 . 5 2 8}$ \\
\cline { 2 - 4 } & Destroyer & 55 & $\mathbf{5 3}$ \\
\cline { 2 - 4 } & Submarino & 16 & $\mathbf{1 6}$ \\
\cline { 2 - 4 } & P-3C (aeronave de & 100 & $\mathbf{9 6}$ \\
& patrulha marítima) & & $\mathbf{4 5 . 9 1 3}$ \\
\hline \multirow{3}{*}{ Aérea } & Pessoal & 44.207 & $\mathbf{2 0 3}$ \\
\cline { 2 - 4 } & F-15J / DJ & 203 & $\mathbf{9 1}$ \\
\cline { 2 - 4 } & F-4EJ & 104 & $\mathbf{7}$ \\
\cline { 2 - 4 } & F-1 & 46 & $\mathbf{2 . 0 6 9}$ \\
\hline \multirow{2}{*}{ Joint Staff Council } & & $\mathbf{1 . 4 0 2}$ & 2000 \\
\hline
\end{tabular}

Fonte: Agência de Defesa, Boei hakusho (Defesa do Japão), 2000 e 2006.

Notas: Números em 31 de março de 2000 e em 31 de março de 2006 (fim dos anos fiscais).

A seguir, será possível localizar onde se encontram atualmente as Forças Militares dos EUA (Figura 1) e as Forças de Autodefesa do Japão (Figura 2). Ambos mapas foram publicados pela Foreign Press Center Japan, no livro Facts and figures of Japan 2007, publicação anual divulgado pelo próprio governo japonês. 


\section{Deployment of US Forces in Japan, 2007}

- Army $\circ$ Navy - Marine Corps $\square$ Air Force
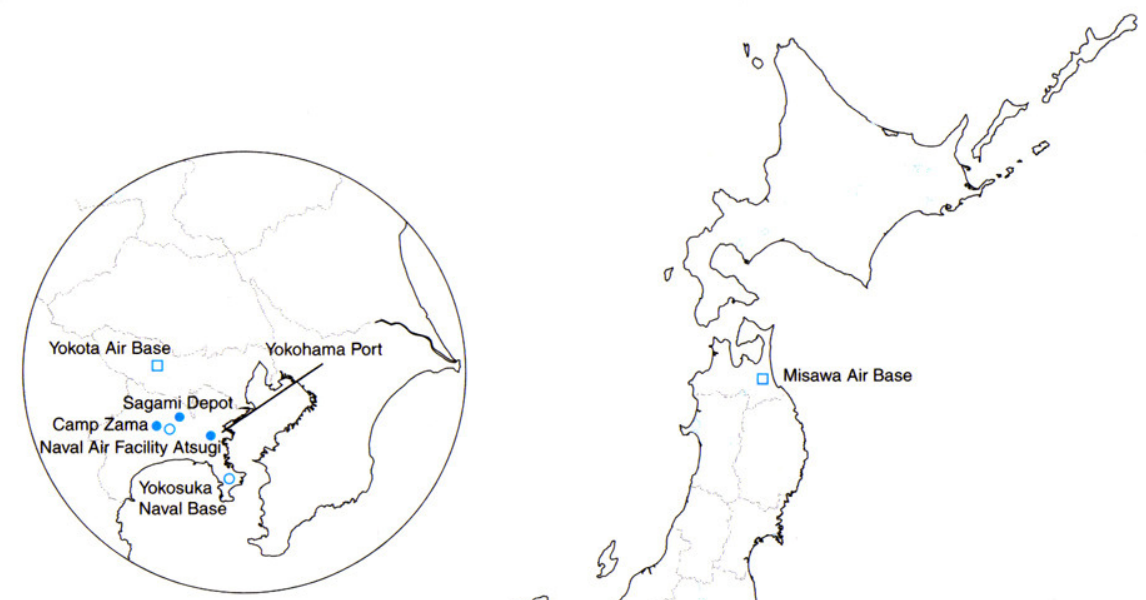

Marine Corps Air Station Iwakun

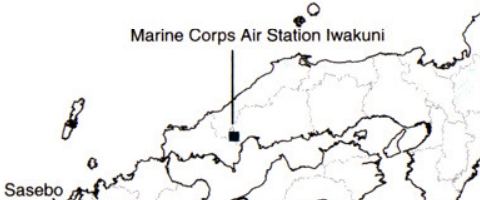

Camp Fuji

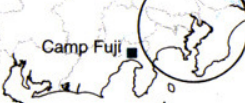

cy

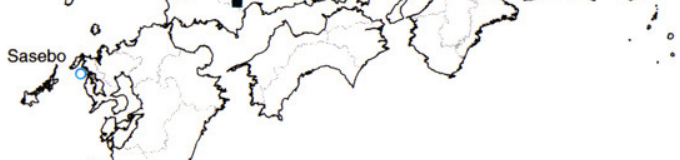

$+3$

of

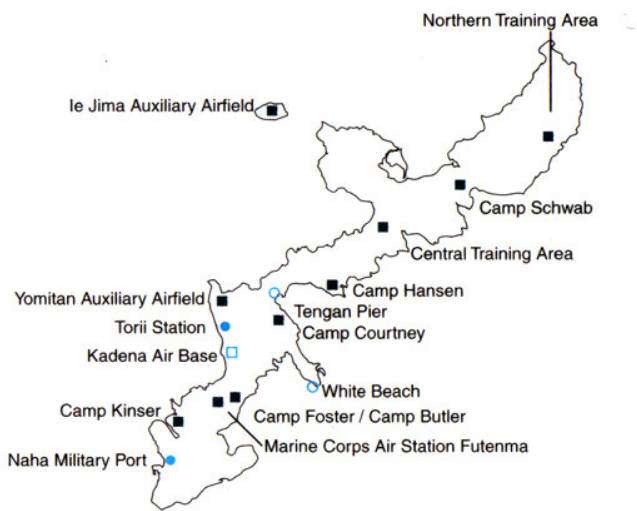

Source: United States Forces, Japan

Figura 1. Forças Militares dos EUA no Japão 


\section{Location of Principal SDF Units}

(As of March 31, 2006)

- Defense Agency

GROUND SELF-DEFENSE FORCE •

- Army Headquarters

Division Headquarters
Brigade Headquarters and Combined Headquarters

Q Airborne Brigades

7 Surface-to-Air Guided Missile Units

- Helicopter Brigades

MARITIME SELF-DEFENSE FORCE •

(1) Self-Defense Fleet Headquarters

(3) Regional District Headquarters

- Principal Naval Bases

† Principal Air Bases (Fixed-Wing Patrol Aircraft Units)

- Principal Air Bases (Patrol Helicopter Units)

AIR SELF-DEFENSE FORCE 。

- Air Defense Command Headquarters

$\diamond$ Air Defense Force Headquarters and Southwestern

4 Fighter Unit

w Ground-to-Air Missile Units

- Aircraft Control and Warning Units (Radar Site)
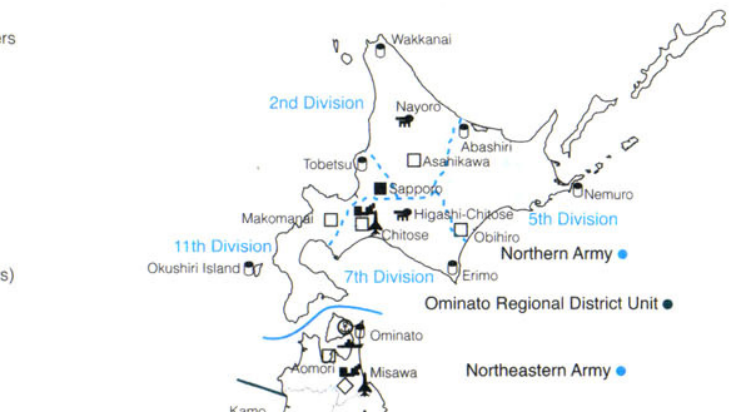

Maizuru Regional District Unit •

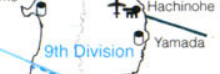

9th Division? Yama

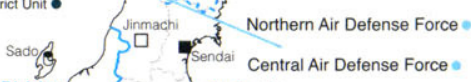

Western Air Defense Force • Middle Army • Komatsul

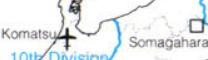

Yokosuka Regional District Unit •

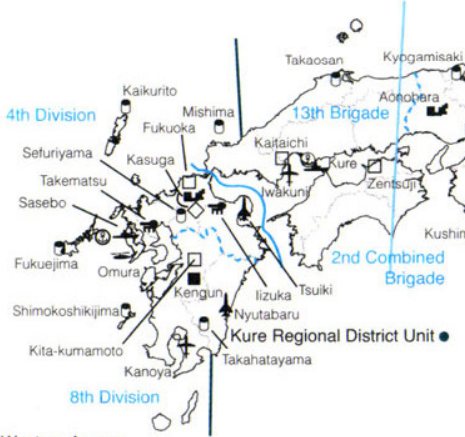

Western Army •

Sasebo Regional District Unit •

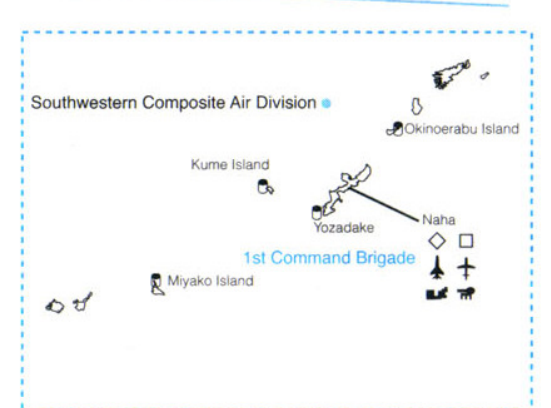

Central Air Defense Force 。

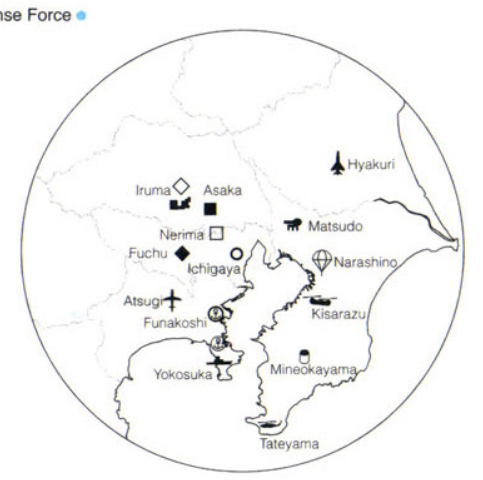

Source: Defense Agency, Boei hakusho (Defense of Japan), 2006.

Figura 2. Forças de Autodefesa do Japão 


\subsection{DE JUNICHIRO KOIZUMI (2001 A 2006) A SHINZO ABE (2006 E 2007)}

O governo do Japão é parlamentarista, cujo órgão máximo representativo do poder do Estado é a Dieta, que consiste na Casa dos Representantes (Câmara Baixa), composta de 480 membros com quatro anos de mandato, e na Casa dos Conselheiros (Câmara Alta), composta por 242 membros com seis anos de mandato. $\mathrm{O}$ primeiro-ministro e a maioria dos ministros do gabinete devem ser membros da Dieta ${ }^{161}$. Normalmente, o líder do partido político com a maioria na Casa dos Representantes é eleito primeiro-ministro ${ }^{162}$.

O partido político de predominância quase hegemônica no pós-guerra é o conservador Partido Liberal Democrata (PLD), que desde sua criação, em 1955, permaneceu ininterruptamente no poder até 1993. O fim do conhecido "Regime de 1955" não durou muito, pois no final de 96 o PLD estava de volta ao poder e no qual permanecer até hoje ${ }^{163}$.

Junichiro Koizumi (PLD) foi eleito primeiro-ministro em 26 de abril de 2001, permanecendo por outros dois mandatos no cargo, até setembro de $2006^{164}$. Seu avô já havia sido ministro do Gabinete e o próprio Koizumi já havia sido ministro da Saúde e do Bem-Estar Social, conquistando o cargo de premiê com promessas de reforma econômica e da privatização da poupança conduzida pelos correios ${ }^{165}$. A eleição de um "ultrareformista”, vem depois de dez anos de recessão da economia japonesa, com crescimento médio anual, entre 1990 e 2000, de 0,5\%; com um índice de desemprego em 4,9\%; e uma inadimplência do sistema bancário de US $\$ 1,2$ trilhão ${ }^{166}$.

Com altos índices de popularidade logo no início de seu mandato, Koizumi logo ganhou ares de estrela, fazendo bastante uso da mídia, especialmente da televisão. Com estilo próprio e bem diferente de seus antecessores, o conhecido fã de Elvis Presley era chamado de Lionheart (“coração de leão") por seus admiradores, por causa de seus cabelos e pela promessa de mudar como as coisas eram feitas ${ }^{167}$. Chegava a escrever em tom informal para o povo na Cabinet E-mail Magazine com esse mesmo apelido ${ }^{168}$.

\footnotetext{
${ }^{161}$ Ver Kodansha International, 2002, p.37.

${ }^{162}$ Ver Foreign Press Center Japan, 2007, p.45-6.

${ }^{163}$ Ver Kodansha International, op. cit., p.39-40.

${ }^{164}$ Ver Foreign Press Center Japan, op. cit., p.49.

${ }^{165}$ Ver BBC Brasil, 2001 (www.bbc.co.uk/portuguese/noticias/2001/010424_japao.shtml).

${ }^{166}$ Ver Dias, 2001 (veja.abril.com.br/020501/p_054.html).

${ }^{167}$ Ver Buruma, 2006 (www.time.com/time/magazine/article/0,9171,1187224,00.html).

${ }^{168}$ Ver koizumi, 2004 (www.kantei.go.jp/foreign/m-magazine/backnumber/2004/1209.html).
} 
Apesar de seu índice de popularidade ter oscilado durante todo o seu governo, Koizumi saiu fortalecido. Em 2005, às vésperas de sua saída em 2006, o Japão apresentava o terceiro ano seguido de crescimento, um PIB de 2,2\%, uma taxa de desemprego recuada para 4,2\%, além do registro de 0,1\% de inflação (primeiro índice de inflação desde 1998, período em que o Japão se encontrava em deflação) ${ }^{169}$. Porém, dentre seus feitos, dois ganharam repercussão internacional, causando polêmicas por serem atos contrários ao Japão pacifista pós-guerra: as visitas anuais a Yasukuni e o envio de tropas japonesas ao Iraque.

Koizumi fez visitas anuais, como primeiro-ministro, ao Memorial Yasukuni, santuário que homenageia "todos os japoneses mortos nas guerras do período moderno", cerca de 2,5 milhões de mulheres, crianças e militares de todas as patentes, que morreram desde a guerra civil de Boshin até a Segunda Guerra Mundial ${ }^{170}$. Dentre os homenageados há condenados por crimes de guerra de classe $\mathrm{A}^{171}$ (julgados culpados com culpa máxima como responsáveis por planejar e levar o país à II Grande Guerra) ${ }^{172}$.

Dentro da crença xintoísta, religião original do Japão, o culto aos antepassados é fundamental para a constituição e manutenção da identidade nipônica ${ }^{173}$. As visitas causaram protestos de países vizinhos, como a China e a Coréia do Sul ${ }^{174}$, ocupados durante vários anos em diversas guerras, já descritas nos capítulos anteriores. Apenas na China foram cerca de 20 milhões de mortes ocasionadas pelos japoneses, principalmente na Ocupação da Manchúria (1931) - com registros de experiências científicas em seres humanos, na Tomada de Nanquim (1937) - extermínio de cerca de 300 mil civis, e durante a Segunda Guerra Mundial (1939 - 1945) - foram 12 milhões de chineses mortos e relatos de provocação de surtos de peste bubônica propositais para fins de uso em guerras bacteriológicas. Adicionalmente há o fato do Japão nunca ter admitido sua culpa por seus crimes de guerra de forma convincente ${ }^{175}$. Os protestos que marcaram o ano de 2005 também tinham outra motivação, a candidatura do Japão a um assento permanente no Conselho de Segurança da ONU, juntamente com Brasil, Índia e Alemanha ${ }^{176}$.

\footnotetext{
${ }^{169}$ Ver Guandalini, 2005 (veja.abril.uol.com.br/091105/p_110.html).

${ }^{170}$ Ver Siqueira, 2005 (www.unb.br/ceam/neasia/boletins/artigo_siqueira190705.pdf).

${ }^{171}$ Ibidem.

${ }^{172}$ Ver Henshall, 2004, p.201,

${ }^{173}$ Ver Siqueira, loc. cit.

${ }^{174}$ Ver BBC Brasil, 2001 (http://www.bbc.co.uk/portuguese/noticias/2001/010813_japao.shtml).

${ }^{175}$ Ver Cordeiro, 2005 (veja.abril.uol.com.br/040505/p_164.html).

${ }^{176}$ France Presse, 2005 (www1.folha.uol.com.br/folha/mundo/ult94u82774.shtml).
} 
O envio das tropas das Forças de Autodefesa ao Iraque entre 2003 e 2006, maior operação militar japonesa fora do país desde o fim da Segunda Guerra, foi um dos atos com maiores índices de rejeição popular, chegando $69 \%$ em determinados momentos. O objetivo era ajudar na reconstrução do Iraque, juntamente com os Estados Unidos e seus aliados, mas tudo dentro da sua constituição pacifista, como transporte de tropas e mercadorias, fornecimento de remédios e assistência sanitária, além de ajuda na reconstrução de edifícios e escolas ${ }^{177}$.

O PLD chegou a apresentar uma proposta para revisão constitucional, para que o país voltasse a ter Forças Armadas, mas com a proibição do Japão participar de guerras. Koizumi defendeu uma ampliação do papel dos japoneses na segurança internacional: "Precisamos assumir os desafios de conflitos que podem ser enfrentados pela sociedade internacional nos próximos 50 anos" ${ }^{" 178}$. No entanto, a revisão constitucional ainda não saiu do papel.

Outra atitude do premiê Koizumi que merece destaque é um projeto de lei que objetivaria a motivação do patriotismo nas escolas japonesas, enviado ao parlamento pelo Gabinete em 2006, pouco antes de sua saída do cargo. As discussões sobre o projeto foram sobre a especulação de ter sido esse mesmo sentimento patriótico que levou o Japão à Segunda Guerra Mundial ${ }^{179}$. Após amplos debates sobre os objetivos reais de tal projeto, em maio de 2007, sob o mandato do primeiro-ministro Shinzo Abe, o parlamento japonês aprovou a lei de incentivo ao patriotismo, que atinge a educação básica do país. $\mathrm{O}$ legislativo aposta no investimento de "normas sociais e de espírito público", levando ao "amor ao país" 180 .

Em 26 de setembro de 2006, Shinzo Abe se torna o novo Primeiro-Ministro do Japão, o mais jovem a ter o cargo (52 anos) e o primeiro nascido pós-guerra. Prometendo dar continuidade às reformas de Koizumi, com cortes no governo, a começar pela renúncia de $30 \%$ de seu salário. Abe também demonstrou ser a favor de mudanças na constituição, especialmente sobre as restrições militares ${ }^{181}$.

\footnotetext{
${ }^{177}$ Ver Sanz, 2006 (noticias.uol.com.br/ultnot/efe/2006/06/20/ult1808u67184.jhtm).

${ }^{178}$ Ver BBC Brasil, 2005 (www.bbc.co.uk/portuguese/noticias/story/2005/11/051122 japaocc.shtml).

${ }^{179}$ Ver BBC Brasil, 2006

(.bbc.co.uk/portuguese/noticias/story/2006/04/060428_japaopatriotismo_crg.shtml).

${ }^{180}$ Ver EFE, 2007

(www.ipcdigital.com/ver_noticiaA.asp?descrldioma=br\&codNoticia $=7285 \&$ codPagina $=7588 \& \operatorname{codSecao}=302$ ).

${ }^{181}$ Ver Veja (veja.abril.com.br/idade/exclusivo/conheca_pais/japao/personagem.html).
} 
Abe vem de uma família de políticos de alto escalão, seu pai, Shintaro Abe, foi ministro da Agricultura, do Comércio e das Relações Exteriores na década de 80, e seu avô, Nobusuke Kishi, foi primeiro-ministro de 1957 a 1960, e, apesar de nunca julgado, foi preso como criminoso de guerra, pois havia feito parte do ministério que assinou a declaração de guerra contra os EUA, durante a II Guerra, em 1941. Já Shinzo Abe, havia sido ministro-chefe de gabinete e porta-voz durante o governo de Koizumi. Antes, ficara conhecido por denunciar, em 2002, o seqüestro de cidadãos japoneses pela Coréia do Norte durante a Guerra Fria ${ }^{182}$.

Logo ao assumir o poder, o conservador Abe, conhecido como "príncipe dos falcões" ("príncipe" por sua educação refinada e "falcão" por seu conservadorismo), modificou a direção do PLD, colocando homens de sua confiança e tão conservadores como ele. Mas seu governo durou pouco, às vésperas de completar um ano, em 12 de setembro de 2007, anunciou a sua renúncia, enfraquecido ao perder popularidade em sua política interna, com a sucessão de escândalos e gafes de seus ministros, principalmente, culminando com o suicídio do ministro da Agricultura, Florestas e Pesca do Japão, Toshikatsu Matsuoka. O escândalo mais grave, que acabou afetando Abe, foi quando veio à tona que no decorrer dos anos o governo havia perdido o registro trabalhista de 50 milhões de trabalhadores ${ }^{183}$.

Porém, a sua política externa trouxe algumas vitórias, como a aproximação com a China, cujas relações se encontravam bastante estremecidas durante o mandato de Koizumi; e uma nova proposta para substituir o Protocolo de Kyoto, chamada "Esfriar a Terra 50", com o objetivo de reduzir pela metade as emissões de gases do efeito estufa, até o ano de $2050^{184}$.

Com relação a defesa do Japão, Shinzo Abe foi responsável por um fortalecimento das Forças de Autodefesa, afinal, é em seu mandato que a Agência de Defesa ganha o status de Ministério da Defesa. E sua busca em destacar o Japão no cenário internacional chegou a ser considerada obsessiva, sempre defendendo a revisão constitucional. Sua postura conservadora provocou reações da China e da Coréia do Sul, quando afirmou não haver evidências de que mulheres daqueles países haviam sido feitas escravas sexuais

182 Ibidem.

${ }^{183}$ Ver Johiyazma, 2006 (www1.folha.uol.com.br/folha/mundo/ult94u100366.shtml); Mexía, 2007 (www1.folha.uol.com.br/folha/mundo/ult94u327689.shtml); BBC News, 2007 (news.bbc.co.uk/2/hi/asiapacific/4392480.stm) e Souza, 2007 (noticias.uol.com.br/ultnot/efe/2007/05/28/ult1808u93221.jhtm).

${ }^{184}$ Ver Mexía, op. cit. e EFE, 2007 (g1.globo.com/Noticias/Ciencia/0,,MUL41448-5603,00.html). Para saber mais sobre "Esfriar a Terra 50", ver Prime Minister of Japan and His Cabinet, 2007 (www.kantei.go.jp/foreign/abespeech/2007/05/24speech_e.html). 
pelos japoneses durante a Segunda Guerra, atitude essa que o levou a um pedido "forçado" de desculpas em público pouco tempo depois ${ }^{185}$.

Em 25 de setembro de 2007, o veterano Yasuo Fukuda do PLD (71 anos) assume o cargo de primeiro-ministro, considerado por muitos a escolha acertada para ser um período de calmaria após a tempestade de escândalos do governo Abe. Fukuda tem um perfil mais moderado e se abstém de políticas mais ambiciosas, como a revisão constitucional de seu antecessor. Além disso, defende laços cordiais com a China; um diálogo com a Coréia do Norte, no caso dos japoneses seqüestrados pela nos anos 70 e 80; e prometeu não fazer visitas ao Memorial de Yasukuni ${ }^{186}$. Porém, essa postura mais moderada de Fukuda ganhou repercussão internacional, quando, no último dia 5 de março de 2008, um suposto ativista japonês de extrema direita se suicidou diante do parlamento em Tóquio. Em carta deixada, o homem pedia ao primeiro-ministro uma postura mais firme na política externa do Japão e com relação ao Santuário de Yasukuni ${ }^{187}$.

O que se nota neste terceiro capítulo é que o Japão parece estar tentando se tornar menos dependente dos Estados Unidos militarmente, inclusive com tentativas abertas de seus políticos de uma revisão constitucional. A elevação de status da Agência de Defesa à Ministério da Defesa é um passo importante nesta direção. E o envio de tropas do Dietai para o Iraque também.

\footnotetext{
${ }^{185}$ Ver Mexía, 2007 (www1.folha.uol.com.br/folha/mundo/ult94u327689.shtml); BBC News, 2007 (news.bbc.co.uk/2/hi/asia-pacific/4392480.stm).

${ }^{186}$ Ver BBC News, 2007 (news.bbc.co.uk/2/hi/asia-pacific/7006285.stm) e EFE e ASSOCIATED PRESS, 2007 (www.estadao.com.br/internacional/not_int56562,0.htm).

${ }^{187}$ Ver BBC Brasil, 2007 (www.bbc.co.uk/portuguese/reporterbbc/story/2008/03/080305_japaosuicidiofn.shtml).
} 


\section{O CENÁRIO INTERNACIONAL NO EXTREMO ORIENTE}

Neste quarto capítulo, o objetivo é esclarecer fatores externos que poderiam motivar a remilitarização japonesa, já que no capítulo anterior foram explicados os cenários internos, militar e político, do Japão. A explanação aqui terá como base: estatísticas militares e episódios acontecidos neste início de século XXI, como o testes de mísseis realizados pela Coréia do Norte. Já apresentado no início desta monografia, os países que são potenciais ameaças ao Japão são os mesmos do início do século passado, Rússia, China e Coréia do Norte (antes, apenas Coréia), todos com passados de guerra ou outras ações militares contra os japoneses.

\subsection{MOTIVAÇÕES E ESTATÍSTICAS}

Os principais motivos da preocupação de defesa nipônica foram resumidos em recente artigo publicado pela revista Veja, em agosto de 2007: a) o sentimento nipônico de que, apesar da presença americana em solo japonês, acredita-se que os EUA não estarão lá quando de fato houver sua necessidade; b) insistência de Washington em fazer o Japão ser mais ativo no papel de sua defesa; c) o temor internacional na Ásia não se resume mais a antiga União Soviética, com a China se tornando uma potência; d) os testes de mísseis da Coréia do Norte, do ditador Kim Jong-II, desde 1998, e o alarde constante sobre o seu programa nuclear $^{188}$.

Adicionado a tudo isso, tem-se o fato do Japão não ter tido países vizinhos com igualdade de economia e avanços sociais e tecnológicos nas primeiras três décadas pósguerra. Mas com a expansão militar e econômica da Rússia, e a modernização da China, o Japão não se encontra mais isolado, sendo afetado geográfico-econômico e politicamente. Até então, os japoneses haviam desenvolvido um forte sentimento de unicidade, de pertencimento somente ao Japão e sendo diferentes de outros povos, mesmo que absorvendo vários elementos culturais, primeiro da China, depois do ocidente. Seu estado isolado do mundo também se deve à barreira lingüística, tanto da dificuldade de aprenderem outras línguas, como de estrangeiros aprenderem o japonês.

${ }^{188}$ Ver Teixeira, 2007, p.82. 
Além disso, os japoneses aplicam a regra hierárquica, tão valorizada em sua sociedade com estrutura vertical, na tentativa de compreender o cenário internacional. Em conseqüência, há um paradoxal complexo de inferioridade e de superioridade que o Japão parece carregar ao mesmo tempo, sendo evidenciado especialmente em relação aos seus vizinhos asiáticos, no caso da China, admirada com o berço da civilização japonesa e rejeitada ao não saber lidar com a modernização do mundo ${ }^{189}$.

Para melhor entender as possíveis preocupações japonesas é preciso compreender como se encontra o cenário militar hoje nesses países, portanto, abaixo segue a Tabela 5, com dados sobre o potencial militar nos principais países do mundo. Comparando o poderia das forças militares da Rússia e China, é possível verificar que ambos têm potencial equivalente aos Estados Unidos, ou seja, o Japão é ainda bastante inferior em relação a esses países.

Tabela 5

Forças militares (2005)

\begin{tabular}{|c|c|c|c|c|c|}
\hline \multirow[b]{2}{*}{ (1.000 pessoas) } & \multicolumn{3}{|c|}{ Forças regulares } & \multirow{2}{*}{$\begin{array}{c}\text { Forças de } \\
\text { reserva }\end{array}$} & \multirow{2}{*}{$\begin{array}{c}\text { Forças } \\
\text { Semi-militares }\end{array}$} \\
\hline & Exército & Marinha & Força Aérea & & \\
\hline Rússia & 395,0 & 142,0 & 160,0 & $20.000,0$ & 415,0 \\
\hline China $^{1}$ & $1.600,0$ & 255,0 & 400,0 & 800,0 & $1.500,0$ \\
\hline Coréia do Sul & 560,0 & 63,0 & 64,0 & $4.500,0$ & 3,5 \\
\hline Índia & $1.100,0$ & 55,0 & 170,0 & $1.155,0$ & $1.293,2$ \\
\hline EUA & 595,9 & 376,8 & 347,4 & 956,2 & - \\
\hline Taiwan & 200,0 & 45,0 & 45,0 & $1.657,0$ & 26,7 \\
\hline Egito & 340,0 & 18,5 & 30,0 & 479,0 & 397,0 \\
\hline Alemanha & 191,4 & 25,7 & 67,5 & 354,7 & - \\
\hline Israel & 125,0 & 8,0 & 35,0 & 408,0 & 8,1 \\
\hline Reino Unido & 112,9 & 53,6 & 50,4 & 241,5 & - \\
\hline França & 133,5 & 44,0 & 63,6 & 216,5 & 104,3 \\
\hline Polônia & 89,0 & 14,3 & 30,0 & 234,0 & 21,4 \\
\hline Japão & 148,2 & $54,2^{2}$ & 45,6 & 44,4 & 12,3 \\
\hline
\end{tabular}

Fonte: The Military Balance 2006, The International Institute for Strategic Studies (in Keizai Koho Center, 2007)

1. Não inclui Taiwan.

2. Força de Autodefesa Marítima e aviação naval.

Na Tabela 6, se encontram o poderio militar da Coréia do Norte, da Coréia do Sul e das forças militares dos EUA baseadas nesse país. Tomando como base os dados das Tabelas 3 e 4, do capitulo 3, nota-se que o Japão ainda é inferior militarmente, mesmo com

${ }^{189}$ Ver Drifte, 1990, p.11-5. 
a presença norte-americana em seu território. Apesar da Coréia do Norte necessitar de ajuda internacional para fornecimento de comida e outras reservas, o país ainda mantém altos índices de capacitação militar, com cerca de 5\% de sua população total na ativa do serviço militar.

Em abril de 2007, a Assembléia do Povo Supremo anunciou que seu orçamento militar era de 15,8\% (do PIB), mas estima-se que essa quantia representa apenas uma parcela dos seus gastos reais. Hoje, o país parece manter um programa para desenvolvimento armas de destruição em massa e de mísseis balísticos. Há suspeitas de que esteja desenvolvendo armas nucleares. Em 1993, não permitiu uma inspeção da Agência de Energia Atômica Internacional e declarou sua retirada do Tratado de NãoProliferação de Armas Nucleares. Para o Japão, tais atitudes são consideradas sérios fatores que desestabilizam o leste da Ásia, o que inclui o próprio Japão ${ }^{190}$.

Na Tabela 7, são detalhadas as forças militares na China, que tenta desenvolver armas nucleares e mísseis balísticos de forma independente desde meados da década de 50. Hoje a China possui mais de uma centena de bombardeiros de médio alcance H-6 (Tu-16), cerca de 30 mísseis balísticos intercontinentais, além de estar desenvolvendo uma nova geração de mísseis estratégicos DF-31 e submarinos para lançamento de mísseis balísticos. É conhecido ainda que no Estreito de Taiwan, a China mantenha mais de 700 mísseis de curto alcance DF-15 e DF-11, número esse que cresce a cada ano. Acredita-se que ela esteja desenvolvendo mísseis de cruzeiro, como complemento das forças de mísseis balísticos, que cobrirá a região da Ásia-Pacífico, incluindo o Japão ${ }^{191}$.

Mesmo assim, a administração de $\mathrm{Hu}$ Jintao promete a construção de uma "sociedade harmoniosa", com uma política que prioriza a solução de problemas domésticos, como a corrupção dentro do Partido Comunista e movimentos separatistas. Internacionalmente, ainda há algumas questões não resolvidas, como Taiwan; e problemas com os Estados Unidos, principalmente sobre Taiwan, proliferação de armas de destruição em massa, direitos humanos. Já com a Rússia, a China mantém um bom relacionamento, com as duas nações objetivando um mundo multipolarizado e com uma nova ordem mundial. A China é hoje a maior compradora de armamentos militares da Rússia, sendo freqüente a troca de visitas de oficiais da Defesa dos dois países. Em 2005 e 2006, o Japão pediu mais transparência nesse comércio de armas entre os dois países. Por último, seu relacionamento tradicional e amigável com a Coréia do Norte tem ajudado a assegurar

\footnotetext{
${ }^{190}$ Ver Japan Ministry of Defense (www.mod.go.jp/e/publ/w_paper/index.html).

${ }^{191}$ Ibidem.
} 
certa estabilidade na região. A Coréia do Norte depende de grandes suprimentos de alimentos e energia da China, mas quando houve o lançamento de mísseis balísticos em 2006 pela Coréia do Norte, a China apoiou a condenação do Conselho de Segurança da ONU e as sanções impostas ao país por seus testes nucleares ${ }^{192}$.

Tabela 6

Potencial militar na península coreana

\begin{tabular}{|c|c|c|c|c|}
\hline \multirow{2}{*}{\multicolumn{2}{|c|}{ Forças armadas totais }} & Coréia do Norte & Coréia do Sul & $\begin{array}{l}\text { Força dos EUA na } \\
\text { Coréia do Norte }\end{array}$ \\
\hline & & $\begin{array}{c}\text { Aprox. } \\
1.100 .000 \text { homens }\end{array}$ & $\begin{array}{c}\text { Aprox. } \\
690.000 \text { homens }\end{array}$ & $\begin{array}{c}\text { Aprox. } \\
29.000 \text { homens }\end{array}$ \\
\hline \multirow{2}{*}{ 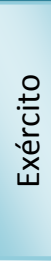 } & Tropas terrestres & $\begin{array}{c}\text { Aprox. } \\
1.100 .000 \text { homens }\end{array}$ & $\begin{array}{c}\text { Aprox. } \\
560.000 \text { homens }\end{array}$ & $\begin{array}{c}\text { Aprox. } \\
20.000 \text { homens }\end{array}$ \\
\hline & $\begin{array}{l}\text { Tanques de } \\
\text { guerra }\end{array}$ & $\begin{array}{c}\text { T-62, T-54/-55 e } \\
\text { outros } \\
\text { Aprox. } 3.500\end{array}$ & $\begin{array}{c}\text { 88, M-47, M-48 e } \\
\text { outros } \\
\text { Aprox. } 2.330\end{array}$ & $\begin{array}{c}\text { M-1 } \\
\text { Aprox. } 110\end{array}$ \\
\hline \multirow{3}{*}{$\frac{\substack{0 \\
\frac{\pi}{c}}}{\frac{\pi}{\frac{\pi}{n}}}$} & $\begin{array}{c}\text { Embarcações } \\
\text { navais } \\
\end{array}$ & $\begin{array}{c}\text { Aprox. } 340 ; \\
109.000 \text { toneladas }\end{array}$ & $\begin{array}{c}\text { Aprox. } 180 ; \\
141.000 \text { toneladas }\end{array}$ & $\begin{array}{c}\text { Somente para } \\
\text { suporte }\end{array}$ \\
\hline & $\begin{array}{l}\text { Destroyers } \\
\text { Fragatas } \\
\text { Submarinos }\end{array}$ & $\begin{array}{l}3 \text { embarcações } \\
23 \text { embarcações }\end{array}$ & $\begin{array}{l}6 \text { embarcações } \\
9 \text { embarcações } \\
9 \text { embarcações }\end{array}$ & - \\
\hline & Fuzileiros & - & $\begin{array}{c}2 \text { divisões; aprox. } \\
28.000 \text { homens }\end{array}$ & - \\
\hline \multirow{2}{*}{ 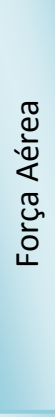 } & $\begin{array}{l}\text { Aeronaves de } \\
\text { combate }\end{array}$ & Aprox. 590 & Aprox. 600 & Aprox. 60 \\
\hline & $\begin{array}{c}\text { Caças de } 3^{a} \text { e } 4^{a} \\
\text { geração }\end{array}$ & $\begin{array}{c}\text { MiG-23 x } 46 \\
\text { aeronaves } \\
\text { MiG-29 x } 20 \\
\text { aeronaves } \\
\text { Su-25 x } 34 \text { aeronaves }\end{array}$ & $\begin{array}{l}\text { F-4 x } 130 \text { aeronaves } \\
\text { F-16 x } 153 \text { aeronaves } \\
\text { F-15 x } 12 \text { aeronaves }\end{array}$ & F-16 x 40 aeronaves \\
\hline \multirow{2}{*}{ 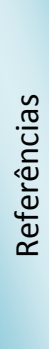 } & População & Aprox. 23.110.000 & Aprox. 48.600 .00 & - \\
\hline & Serviço militar & $\begin{array}{c}\text { Exército: 5-12 anos } \\
\text { Marinha: 5-10 anos } \\
\text { Força Aérea: 3-4 anos }\end{array}$ & $\begin{array}{c}\text { Exército: } 24 \text { meses } \\
\text { Marinha: } 26 \text { meses } \\
\text { Força Aérea: } 27 \\
\text { meses }\end{array}$ & - \\
\hline
\end{tabular}

Fonte: The Military Balance 2007 (in Japan Ministry of Defense http://www.mod.go.jp/e/publ/w_paper/index.html) 
Tabela 7

Potencial militar na China

\begin{tabular}{|c|c|c|c|}
\hline & & China & $\begin{array}{l}\text { Taiwan } \\
\text { (referência) }\end{array}$ \\
\hline & Forças armadas totais & 2.250.000 homens & 290.000 homens \\
\hline & Tropas terrestres & $\begin{array}{c}\text { Aprox. } \\
1.600 .000 \text { homens }\end{array}$ & $\begin{array}{c}\text { Aprox. } \\
\text { 290.000 homens }\end{array}$ \\
\hline 帝 & Tanques de guerra & $\begin{array}{l}\text { Type-98A, Type-96, Type- } \\
\text { 88A/B e outros Aprox. } 8.580\end{array}$ & $\begin{array}{c}\text { M-60, M-48A/H e outros } \\
\text { Aprox. } 1.830\end{array}$ \\
\hline & Embarcações navais & $\begin{array}{c}\text { Aprox. } 780 \\
1.070 .000 \text { toneladas }\end{array}$ & $\begin{array}{c}\text { Aprox. 330; } \\
207.000 \text { toneladas }\end{array}$ \\
\hline$\cdot \frac{\sqrt{\pi}}{\pi}$ & Destroyers e Fragatas & Aprox. 70 embarcações & Aprox. 30 embarcações \\
\hline$\sum^{10}$ & Submarinos & Aprox. 60 embarcações & 4 embarcações \\
\hline & Fuzileiros & Aprox. 10.000 homens & Aprox. 15.000 homens \\
\hline$\stackrel{\pi}{(\pi}$ & Aeronaves de combate & Aprox. 3.520 & Aprox. 530 \\
\hline 芯 & Caças modernos & $\begin{array}{c}\mathrm{J}-10 \times 62 \text { aeronaves } \\
\text { Su-27 × } 148 \text { aeronaves } \\
\text { Su-30 } 121 \text { aeronaves } \\
\end{array}$ & $\begin{array}{c}\text { Mirage } 2000 \text { x } 57 \text { aeronaves } \\
\text { F-16 x } 146 \text { aeronaves } \\
\text { Ching-Kuo x } 128 \text { aeronaves }\end{array}$ \\
\hline$\frac{\tilde{\pi}}{\frac{\pi}{2}}$ & População & Aprox. 1.300.000.000 & Aprox. 23.000.000 \\
\hline$\underset{\mathscr{d}}{\mathscr{d}}$ & Serviço militar & 2 anos & 20 meses \\
\hline
\end{tabular}

Fonte: The Military Balance 2007 (in Japan Ministry of Defense -

www.mod.go.jp/e/publ/w_paper/index.html)

A Rússia tem como questão pendente com o Japão as ilhas Curilas (arquipélago formado por 56 ilhas), foco de impasses diplomáticos até hoje. O Japão alega que a Rússia tem utilizado militarmente as ilhas de Kunashiri, Etorofu e Shikotan, territórios considerados parte integral do Japão. Os japoneses alegam que os russos estão ocupando tais locais ilegalmente. Apesar de ter diminuído o contingente de tropas a partir de 1993, com o presidente Boris Yeltsin no poder, a última resposta oficial do governo russo foi em julho de 2006, quando o então ministro da Defesa Ivanov, disse que não aumentaria ou diminuiria as tropas baseadas no local (3.500 soldados) ${ }^{193}$.

Quanto ao seu potencial militar, presume-se que haja cerca de 90 mil homens, 250 navios de guerra (600 mil toneladas) e 630 aeronaves de combate, além do armamento 
nuclear. O reduzido número de homens se deve a reforma militar recente naquele país. Ainda como grande exportador de armamentos militares, a Rússia utiliza isso como meio de manutenção de suas forças militares, promoção de sua política externa, além dos $\operatorname{lucros}^{194}$.

\subsection{EPISÓDIOS SIGNIFICANTES}

Neste início de século, alguns episódios considerados incidentes diplomáticos acontecidos merecem destaque por serem motivadores para uma remilitarização do Japão. A começar por um encontro realizado pela primeira vez por um chefe do governo japonês, o então primeiro-ministro Shinzo Abe, em janeiro de 2007, à sede da Organização do Tratado do Atlântico Norte (OTAN), marcando a continuidade do diálogo estratégico entre os dois, já iniciado nos anos $90^{195}$.

A Coréia do Norte lança, em 5 de julho de 2006, sete mísseis balísticos (um de longo alcance e os outros de médio alcance), que caem no Mar do Japão. Em resposta, as Nações Unidas adotou as Resoluções 1695 e 1718, além da imposição de sanções econômicas, o que significava a demanda da suspensão imediata de todas as atividades referentes ao lançamento dos mísseis, bem como a suspensão do envio quaisquer materiais por outros países que possa sustentar tal programa de mísseis, e a volta do país ao debate do $\mathrm{TNP}^{196}$.

No dia 9 de outubro do mesmo ano, a Coréia do Norte anuncia que realizou com sucesso um teste nuclear subterrâneo, com segurança. Coincidência ou não, apenas quatro dias depois, as Nações Unidas elegem o sul-coreano Ban Ki-moon como o seu novo secretário geral. Em 14 de outubro, a ONU adota com unanimidade a Resolução 1718, com imposição de sanções. Ainda em 2006, em 19 de dezembro, a Assembléia Geral da ONU

194 Ibidem

${ }^{195}$ Ver Ikegami (www.nato.int/docu/review/2007/issue2/portuguese/art4.html).

${ }^{196}$ Ver Japan Ministry of Defense (www.mod.go.jp/e/publ/w_paper/index.html); Ikegami (www.nato.int/docu/review/2007/issue2/portuguese/art4.html); G1, 2007 (g1.globo.com/Noticias/Mundo/0,,MUL41957-5602,00.html); e Esteves, 2006 (www.pucminas.br/imagedb/conjuntura/CNO_ARQ_NOTIC20060830093826.pdf?PHPSESSID=b7c16959e7d 5384b6977cdbc9367ab70). 
adota uma resolução condenando o seqüestro de cidadãos estrangeiros pela Coréia do Norte $^{197}$.

Sobre a China, o Exército Popular de Libertação (EPC) tem obtido cada vez mais poder militar, inclusive com a aquisição de armamento ofensivo. Sabe-se que ele tem preparado operações contra o Japão, já que Tóquio daria apoio logístico em caso de uma suposta intervenção dos Estados Unidos, na questão de Taiwan. Em 2004, um submarino foi detectado em águas nipônicas, enquanto a invasão de seu espaço aéreo estar cada vez mais freqüente, passando de 13 vezes em 2004, para 107 em 2005. Em 2006, um submarino de ataque do EPC seguiu submergido um porta-aviões americano baseado no Japão, sendo detectado apenas quando veio à superfície ${ }^{198}$.

Em 16 de agosto de 2006, um pescador japonês morreu ao ter seu barco alvejado por uma patrulha russa próximo às Ilhas Curilas, outros três pescadores foram detidos. $\mathrm{O}$ Ministério dos Assuntos Exteriores da Rússia alegou que a culpa era dos pescadores "clandestinos" "199. Em 9 de fevereiro de 2008, o Ministério da Defesa do Japão relatou a invasão de seu espaço aéreo por um bombardeiro russo Tu-95. Em resposta, a Força Aérea Russa disse que o avião estava uma missão de rotina e sobre águas internacionais, mas incidente semelhante havia acontecido em $2006^{200}$.

Com o potencial militar cada vez maior na região, o Japão tem razões para se sentir ameaçado, especialmente com episódios recentes de demonstração de força por seus vizinhos. Até agora os incidentes foram todos lidados de forma diplomática, pois não houve graves conseqüências, mas a pergunta que se deve considerar é se incidentes não se tornarão mais graves ou mais freqüentes.

${ }^{197}$ Ver Japan Ministry of Defense

(www.mod.go.jp/e/publ/w_paper/pdf/2007/46Defence\%20Chronology.pdf).

${ }^{198}$ Ver Ikegami (www.nato.int/docu/review/2007/issue2/portuguese/art4.html).

${ }^{199}$ Ver BBC Brasil, 2006

(http://www.bbc.co.uk/portuguese/noticias/story/2006/08/060816_pescadorjaponesrw.shtml) e EFE, 2006 (www.ipcdigital.com/ver_noticiaA.asp?descrldioma=br\&codNoticia=2992\&codPagina=3085 \&codSecao=302).

${ }^{200}$ Ver Japan Ministry of Defense, 2008 (www.mod.go.jp/e/publ/lastest/press20080209.html) e EFE, 2008 (www.estadao.com.br/internacional/not_int121948,0.htm). 


\section{CONCLUSÃO}

O objetivo desta monografia era compreender o porquê de haver a intenção de uma possível remilitarização pelo Japão neste início de século. Por isso, houve uma contextualização histórica e uma análise do cenário atual doméstico e internacional na região.

No primeiro capítulo é possível notar que as raízes da nação que existe hoje se fundamentam principalmente no fim do século XIX, quando o Japão aprende e adapta novas tecnologias, especialmente as militares, que o ocidente introduz. O fato de o Japão ter sido uma nação expansionista, que levou à prática seus sonhos de conquistas territoriais, foi o início das inimizades, até declaradas, que sofre na região. À época, talvez o país não tivesse outra opção, escolhendo ser conquistador do que ser conquistado, com uma potência como a União Soviética tão próxima oferecendo certa ameaça à sua soberania.

Com a ocupação americana em território nipônico, logo após o fim da Segunda Guerra, a desmilitarização logo se tornou realidade, oficializada permanentemente com a nova constituição e a inclusão do artigo de renúncia à guerra, como visto no segundo capítulo.

O Japão hoje é conhecido por ser um dos países com maior economia do mundo, além de ter seu povo como harmonioso e pacífico. Porém, a possível remilitarização está cada vez mais próxima da realidade, principalmente com o aparecimento de líderes japoneses com intenções de uma revisão constitucional, como se pôde perceber no terceiro capítulo. Ainda não há previsão concreta sobre isso, já que o atual primeiro ministro Fukuda tem uma postura mais moderada e menos conservadora que seus antecessores, Shinzo Abe e Junichiro Koizumi.

Por fim, é possível compreender com o quarto e último capítulo que com todos os recentes episódios descritos como incidentes diplomáticos, entre o Japão e seus vizinhos, faz-se ainda mais importante e urgente que o país cogite que suas Forças de Autodefesa se tornem forças militares. A dependência de forças americanas para defesa do Japão, pelo Tratado de Segurança e Cooperação Mútua, pode não ser suficiente. 


\section{REFERÊNCIAS BIBLIOGRÁFICAS}

ALPEROVITZ, G. Atomic diplomacy: Hiroshima and Potsdam: the use of the atomic bomb and the American confrontation with Soviet power. Harmondsworth: Penguin, $1965 / 1985$.

BARNETT, A. Doak. China and the Major Powers in East Asia. Washington: The Bookings Institution, 1977. $418 \mathrm{p}$.

CERVO, Amado Luiz. A Instabilidade Internacional (1919-1939). In: SARAIVA, José Flávio Sombra (org.). História das Relações Internacionais Contemporâneas: da Sociedade Internacional do Século XIX à Era da Globalização. São Paulo: Saraiva, 2007. 348 p.

CROWLEY, James H. Japan's Military Foreign Policy. In: MORLEY, James William. Japan's foreign policy: 1868-1941. Nova Iorque: Columbia University Press, 1974. 624 p.

DRIFTE, Reinhard. Japan's foreign policy. Londres: Chatham House Papers, 1990. 118 p.

FOREIGN PRESS CENTER JAPAN. Facts and figures of Japan 2007.Tóquio: Foreign Press Center Japan, 2007, 224 p.

GREENE, Fred. Stresses in U.S.-Japanese security relations. Washington, D.C.: The Brookings Institution, 1975, $110 \mathrm{p}$.

HENSHALL, Kenneth G. História do Japão. 2 ed. Lisboa: Edições 70, 2004. 304 p.

INOUE, Kyoko. MacArthur's Japanese constitution. Chicago: The University of Chicago Press, 1991. 382 p.

INTERNATIONAL SOCIETY FOR EDUCATION FORMATION. Japan in modern society. 1 ed. Tóquio: Shobundo Company Ltda, 1995. 469 p.

JAMES, D. Clayton. The years of MacArthur. 3 vols. Boston: Houghton Mifflin Company, 1985.

KATZENSTEIN, Peter J. Cultural norms and national security: policy and military in postwar Japan. Nova Iorque: Cornell University Press, 1996. 312 p.

KODANSHA INTERNATIONAL LTD. The Japan book. Tóquio: Kodansha International, 2002. $160 \mathrm{p}$.

MACARTHUR, Douglas. Reminiscences. Nova Iorque: McGraw Hill Co., 1964. 
MARTINS, Marcus Philipe Peres. Um golpe no imperialismo. Desvendando a História. São Paulo, n. 16, p.54-59, ano 3, 2007.

MILITARY SITUATION IN THE FAR EAST: HEARINGS BEFORE THE COMMITTEE ON ARMED SERVICES AND THE COMMITTEE ON FOREIGN RELATIONS, United States Senate, $82^{\text {nd }}$ Congress, $1^{\text {st }}$ Session; Part I, p.223.

REISCHAUER, Edwin O. Japan: the story of a nation. 4 ed. Tóquio: Charles E. Turttle Company, 1971. 384 p.

REISCHAUER, E. e CRAIG, A. Japan: tradition and transformation. Londres, Boston e Sidney: George Allen \& Unwin, 1979.

SARAIVA, José Flávio Sombra. A Agonia Européia e a Gestação da Nova Ordem Internacional. In: SARAIVA, José Flávio Sombra (org.). História das relações internacionais contemporâneas: da sociedade internacional do século XIX à era da globalização. São Paulo: Saraiva, 2007. 348 p.

SAYLE, M. Did the bomb end the war? New Yorker, 31 de julho de 1995, pp.40-64.

TAKAYANAGI, Kenzō; ŌTOMO, Ichirō; e TANAKA, Hideo. Nihonkoku kempō seiteino katei (The making of the Japanese constitution). 2 vols. Tóquio: Yūhikaku, 1972.

TEIXEIRA, Duda. De volta às armas. Veja, São Paulo, ed. 2.019, no 30, p. 80 e 82, 1 de agosto de 2007.

UNITED STATES DEPARTMENT OF DEFENSE. United States' Vietnam relations, 1945-67. Book 2 (1950-52). Washington: US Government Printing Office, 1945-52. P.434-5.

U.S. ARMY. Reports of General MacArthur. Vol. 1 supplement, MacArthur in Japan: the occupation: military phase, prepared by his general staff. Washington, D.C.: Government Printing Office. 1966.

WARD, Robert E., and Yoshikazu Sakamoto, eds. Democratizing Japan: the allied occupation. Honolulu: University of Hawaii Press, 1987.

WELFIELD, John. An empire in eclipse: Japan in the postwar american alliance system: a study in the interaction of domestic politics and foreign policy. 1 ed. Londres: The Athlone Press, 1988. 516 p.

WILLIAMS, P. e WALLACE, D. Unit 731: the Japanese army's secret of secrets. Londres: Hodder \& Stoughton, 1989. 


\section{BIBLIOGRAFIA ELETRÔNICA}

BBC Brasil. 'Ativista' japonês comete suicídio em frente a parlamento. 5 de março de 2008. Disponível em:

<http://www.bbc.co.uk/portuguese/reporterbbc/story/2008/03/080305_japaosuicidiofn.sht ml>. Acesso em: 10 de março de 2008.

BBC Brasil. Japão pode alterar sua constituição pacifista. 22 de novembro de 2005. Disponível em:

$<$ http://www.bbc.co.uk/portuguese/noticias/story/2005/11/051122_japaocc.shtml>. Acesso em: 10 de março de 2008.

BBC BRASIL. Pescador japonês morre alvejado por patrulha russa. 16 de agosto de 2006. Disponível em:

<http://www.bbc.co.uk/portuguese/noticias/story/2006/08/060816_pescadorjaponesrw.sht $\mathrm{ml}>$. Acesso em: 11 de março de 2008.

BBC BRASIL. Primeiro-ministro japonês causa polêmica ao visitar Yasukuni. 13 de agosto de 2001. Disponível em:

<http://www.bbc.co.uk/portuguese/noticias/2001/010813_japao.shtml>. Acesso em: 08 de março de 2008.

BBC Brasil. Projeto japonês 'pró-patriotismo' provoca polêmica. 28 de abril de 2006. Disponível em:

<http://www.bbc.co.uk/portuguese/noticias/story/2006/04/060428_japaopatriotismo_crg.sh tml>. Acesso em: 10 de março de 2008.

BBC Brasil. Protestos contra o Japão se espalham pela China. 10 de abril de 2005. Disponível em:

<http://www.bbc.co.uk/portuguese/noticias/story/2005/04/050410_chinarcmvv.shtml>. Acesso em: 10 de março de 2008.

BBC BRASIL. Reformista deve ser o novo primeiro-ministro do Japão. 24 de abril de 2001. Disponível em:

<http://www.bbc.co.uk/portuguese/noticias/2001/010424_japao.shtml>. Acesso em: 08 de março de 2008.

BBC NEWS. Profile: Junichiro Koizumi. 12 de setembro de 2005. Disponível em: <http://news.bbc.co.uk/1/hi/world/asia-pacific/1293536.stm>. Acesso em: 09 de março de 2008.

BBC NEWS. Profile: Shinzo Abe. 12 de setembro de 2007.Disponível em:

<http://news.bbc.co.uk/2/hi/asia-pacific/4392480.stm>. Acesso em: 10 de março de 2008. 
BBC NEWS. Profile: Yasuo Fukuda. 23 de setembro de 2007. Disponível em: <http://news.bbc.co.uk/2/hi/asia-pacific/7006285.stm>. Acesso em: 10 de março de 2008.

BURUMA, Ian. Junichiro Koizumi. Time, 30 de abril de 2006. Disponível em: $<$ http://www.time.com/time/magazine/article/0,9171,1187224,00.html>. Acesso em: 09 de março de 2008.

CORDEIRO, Tiago. Crime sem perdão. Veja, ed.1.903, 4 de maio de 2005. Disponível em: <http://veja.abril.uol.com.br/040505/p_164.html>. Acesso em: 10 de março de 2008.

DIAS, Cristiano. No comando, Reformista-san. Veja, ed. 1.698, 2 de maio de 2001.

Disponível em: <http://veja.abril.com.br/020501/p_054.html>. Acesso em: 10 de março de 2008.

EFE. Japão acusa Rússia de invadir seu espaço aéreo. 9 de fevereiro de 2008.

Disponível em: <http://www.estadao.com.br/internacional/not_int121948,0.htm>. Acesso em: 11 de março de 2008.

EFE. Japão quer cortar CO2 pela metade até 2050. 24 de maio de 2007. Disponível em: <http://g1.globo.com/Noticias/Ciencia/0,,MUL41448-5603,00.html>. Acesso em: 10 de março de 2008.

EFE. Parlamento aprova lei de incentivo ao patriotismo. Publicado em IPCDigital, 18 de maio de 2007. Disponível em:

$<$ http://www.ipcdigital.com/ver_noticiaA.asp?descrIdioma=br\&codNoticia=7285\&codPag ina $=7588 \& \operatorname{codSecao}=302>$. Acesso em: 10 de março de 2008.

EFE. Rússia entregará cadáver de japonês. Publicado em IPCDigital, 18 de agosto de 2006. Disponível em:

$<$ http://www.ipcdigital.com/ver_noticiaA.asp?descrIdioma=br\&codNoticia=2992\&codPag ina $=3085 \&$ codSecao $=302>$. Acesso em: 11 de março de 2008.

EFE e ASSOCIATED PRESS. Parlamento japonês proclama Yasuo Fukuda primeiroministro. Publicado por O Estado de S. Paulo, 25 de setembro de 2007. Disponível em: < http://www.estadao.com.br/internacional/not_int56562,0.htm>. Acesso em: 10 de março de 2008.

ESTEVES, Raphael Rezende. Teste com mísseis balísticos como tentativa de fortalecimento do poder de barganha norte-coreano. Cenários PUC Minas: Conjuntura Internacional, 25 de agosto de 2006. Disponível em:

<http://www.pucminas.br/imagedb/conjuntura/CNO_ARQ_NOTIC20060830093826.pdf? PHPSESSID=b7c16959e7d5384b6977cdbc9367ab70>. Acesso em: 11 de março de 2008. 
FRANCE PRESSE. China prepara segunda onda de manifestações contra o Japão. FolhaOnline, 14/04/2005. Disponível em: <www1.folha.uol.com.br/folha/mundo/ult94u82774.shtml>. Acesso em: 10 de março de 2008.

G1. Coréia do Norte dispara mísseis em direção ao Mar do Japão. 25 de maio de 2007. Disponível em: < http://g1.globo.com/Noticias/Mundo/0,,MUL41957-5602,00.html>. Acesso em: 11 de março de 2008.

GUANDALINI, Giuliano. A nova e boa notícia que vem da Ásia. Veja, Ed. 1.930, 9 de novembro de 1995. Dispónível em: <http://veja.abril.uol.com.br/091105/p_110.html>. Acesso em: 10 de março de 2008.

IKEGAMI, Masako. A OTAN e o Japão: o fortalecimento da estabilidade da Ásia. Disponível em: <http://www.nato.int/docu/review/2007/issue2/portuguese/art4.html>. Acesso em: 11 de março de 2007.

JAPAN MINISTRY OF DEFENSE. I. Constitution of Japan and right of self-defense. Disponível em: <http://www.mod.go.jp/e/d_policy/dp01.html>. Acesso em: 03 de março de 2008.

JAPAN MINISTRY OF DEFENSE. II. Basis of defense policy. Disponível em: <http://www.mod.go.jp/e/d_policy/dp02.html>. Acesso em: 03 de março de 2008.

JAPAN MINISTRY OF DEFENSE. III. Japan-U.S. security arrangements. Disponível em: < http://www.mod.go.jp/e/d_policy/dp03.html>. Acesso em: 03 de março de 2008. JAPAN MINISTRY OF DEFENSE. Defense of Japan 2007. Disponível em:

$<$ <ttp://www.mod.go.jp/e/publ/w_paper/index.html>. Acesso em: 11 de março de 2008.

JAPAN MINISTRY OF DEFENSE. Defense chronology. Disponível em:

<http://www.mod.go.jp/e/publ/w_paper/pdf/2007/46Defence\%20Chronology.pdf>. Acesso em: 11 de março de 2008.

JAPAN MINISTRY OF DEFENSE. United States-Japan roadmap for realignment implementation (may 1, 2006). Disponível em:

<http://www.mod.go.jp/e/d_policy/dp13.html>. Acesso em: 08 de março de 2008.

JAPAN MINISTRY OF DEFENSE. Violation of Japanese airspace by Russian aircraft (february 9, 2008). Disponível em:

$<$ http://www.mod.go.jp/e/publ/lastest/press20080209.html>. Acesso em: 11 de março de 2008 .

JOHIYAZMA, Mie. Shinzo Abe é o mais jovem premiê do Japão desde 1945. France Presse publicado por Folha Online, 26 de setembro de 2006. Disponível em: 
<http://www1.folha.uol.com.br/folha/mundo/ult94u100366.shtml>. Acesso em: 10 de março de 2008.

KEIZAI KOHO CENTER. Japan 2007: An international comparison. Disponível em: <http://www.kkc.or.jp/english/activities/publications/aic2007.pdf >. Acesso em: $11 \mathrm{de}$ março de 2008.

KOIZUMI, Junichiro. Apples at 2,000 yen each. Koizumi Cabinet E-mail Magazine, $\mathrm{n}^{\mathbf{o}}$ 167, 9 de dezembro de 2004. Disponível em: <http://www.kantei.go.jp/foreign/mmagazine/backnumber/2004/1209.html>. Acesso em: 09 de março de 2008.

MATTOS, Leonel Oliveira e SARTI, Ana Rosa R. de M. O impacto das reformas estruturais do governo Koizumi no quadro de estagnação japonês. Disponível em: <http://www.prp.unicamp.br/pibic/congressos/xvcongresso/paineis/033996.pdf>. Acesso em: 07 de março de 2008.

MEXÍA, Fernando. Análise: renuncia Shinzo Abe, um "príncipe" sem liderança. EFE publicado por FolhaOnline, 12 de setembro de 2007. Disponível em:

$<$ http://www1.folha.uol.com.br/folha/mundo/ult94u327689.shtml >. Acesso em: $10 \mathrm{de}$ março de 2008.

PRIME MINISTER OF JAPAN AND HIS CABINET. Invitation to "Cool Earth 50" - 3 Proposals, 3 Principles. 24 de maio de 2007. Disponível em:

<www.kantei.go.jp/foreign/abespeech/2007/05/24speech_e.html>. Acesso em: 10 de março de 2008.

SANZ, Juan Antonio. Primeiro-ministro do Japão anuncia retirada de tropas do Iraque. EFE publicado por UOL Úlitmas Notícias, 20 de junho de 2006. Disponível em: $<$ http://noticias.uol.com.br/ultnot/efe/2006/06/20/ult1808u67184.jhtm>. Acesso em: 10 de março de 2008.

SIQUEIRA, Juliano Carvalho. Premier Koizumi, nacionalismo, xintoísmo e o Santuário de Yasukuni. Disponível em:

<http://www.unb.br/ceam/neasia/boletins/artigo_siqueira190705.pdf>. Acesso em: 07 de março de 2008.

SOUZA, Patrícia. Ministro japonês se suicida em meio a escândalo por corrupção. EFE publicado por UOL Últimas Notícias, 28 de maio de 2007. Disponível em: <http://noticias.uol.com.br/ultnot/efe/2007/05/28/ult1808u93221.jhtm>. Acesso em: 10 de março de 2008.

U.S. DEPARTMENT OF DEFENSE. Base structure report (listing of facilities) fiscal year 2003. Disponível em: 
<http://www.defenselink.mil/news/Jun2003/basestructure2003.pdf>. Acesso em: 24 de fevereiro de 2008.

U.S. DEPARTMENT OF DEFENSE. Base structure report (listing of facilities) fiscal year 2004. Disponível em:

<http://www.defenselink.mil/pubs/20040910_2004BaseStructureReport.pdf>. Acesso em: 24 de fevereiro de 2008.

U.S. DEPARTMENT OF DEFENSE. Base structure report (listing of facilities) fiscal year 2005. Disponível em: <http://www.defenselink.mil/pubs/20050527_2005BSR.pdf>. Acesso em: 24 de fevereiro de 2008.

U.S. DEPARTMENT OF DEFENSE. Base structure report (listing of facilities) fiscal year 2006. Disponível em: <http://www.defenselink.mil/pubs/BSR_2006_Baseline.pdf>. Acesso em: 24 de fevereiro de 2008.

U.S. DEPARTMENT OF DEFENSE. Base structure report (listing of facilities) fiscal year 2007. Disponível em: <http://www.defenselink.mil/pubs/BSR_2007_Baseline.pdf>. Acesso em: 24 de fevereiro de 2008.

VEJA. Shinzo Abe não quer constituição pacifista. Disponível em:

$<$ http://veja.abril.com.br/idade/exclusivo/conheca_pais/japao/personagem.html>. Acesso em: 10 de março de 2008.

WASHINGTON POST. Shinzo Abe's double talk. Editorial, página A16, 24 de março de 2007. Disponível em: <http://www.washingtonpost.com/wpdyn/content/article/2007/03/23/AR2007032301640.html>. Acesso em: 10 de março de 2008.

WEB JAPAN. The Constitution of Japan. Patrocinada pelo Ministério dos Negócios Estrangeiros do Japão. Disponível em: <http://webjapan.org/factsheet/pdf/CONSTITU.pdf>. Acesso em: 19 de janeiro de 2008. No original em japonês: http://web-japan.org/factsheet/ja/pdf_Japanese/J09_consti.pdf 